\title{
Sexual selection in wild baboons: from mating opportunities to paternity success
}

\author{
SUSAN C. ALBERTS* $†$, JASON C. BUCHAN* \& JEANNE ALTMANN† \\ ${ }^{*}$ Department of Biology, Duke University \\ $\dagger$ Institute for Primate Research, National Museums of Kenya, Nairobi \\ $\ddagger$ Department of Ecology and Evolutionary Biology, Princeton University \\ $\S$ Department of Conservation Biology, Chicago Zoological Society, Brookfield, Illinois, U.S.A. \\ (Received 18 April 2006; initial acceptance 1 May 2006; \\ final acceptance 17 May 2006; published online 9 October 2006; MS. number: A10423)
}

\begin{abstract}
In mammals, high dominance rank among males is often associated with mating success. However, mating opportunities do not automatically translate into offspring production; observed mating success may be discordant with offspring production, for three reasons. (1) Observed mating may be nonrepresentative of actual mating if some mating is surreptitious (decreasing the chance that it will be observed), (2) mating may be nonrandom if some males allocate more mating effort to females with high fertility (i.e. if some males differentially invest in higher fertility mating) and (3) conception success may be nonrandom if sperm competition or sperm selection play a role in conception. We performed a genetic analysis of paternity in the well-studied savannah baboon, Papio cynocephalus, population in the Amboseli basin, eastern Africa, in order to measure the concordance between observed mating success and actual offspring production. We found that observed mating success was generally a good predictor of paternity success, that high-ranking males had higher paternity success than lower-ranking males, and that male density and male rank stability contributed to variance in male paternity success. We found little evidence for successful surreptitious mating (although subadult males did occasionally produce offspring, apparently using this strategy), and no clear evidence for differential sperm success or sperm depletion (although we could not rule them out). However, we found clear evidence that high-ranking males showed mate choice, concentrating their mating efforts on females experiencing conceptive rather than nonconceptive cycles.
\end{abstract}

(c) 2006 The Association for the Study of Animal Behaviour. Published by Elsevier Ltd. All rights reserved.

In many mammals, males with high dominance rank experience mating advantages over lower-ranking males (e.g. LeBoeuf 1974; Clutton-Brock et al. 1982; Poole 1989; Moore et al. 1995; Preston et al. 2001; Say et al. 2001). In primates, the advantage of high rank is pronounced, although variable both within and across species (reviewed in Cowlishaw \& Dunbar 1991; Bulger 1993; Alberts et al. 2003; Altmann \& Alberts 2003a). The advantage of high rank for mating success indicates sexual selection for fighting ability (the primary determinant of rank in primates). However, there is certainly sexual selection on traits other than fighting ability, and there are other sources of variance in male mating and paternity success.

Correspondence and present address: S. C. Alberts, Department of Biology, Duke University, Box 90338, Durham NC 27705, U.S.A. (email: alberts@duke.edu).J. C. Buchan is now at the Forensic Science Service Tasmania, New Town, Tasmania 7008, Australia. J. Altmann is at the Department of Ecology and Evolutionary Biology, Princeton University, Princeton, NJ 08544, U.S.A.
We have a good understanding of some sources of variance in mating success for male primates (Cowlishaw \& Dunbar 1991; Bulger 1993; Weingrill et al. 2000; Alberts et al. 2003; Weingrill et al. 2003). In particular, we know that high-ranking males are unable to monopolize reproductive opportunities when more than one female is simultaneously in oestrus; the effects of oestrus synchrony on male reproductive success are incorporated into the priority of access model, in which the degree of cycle overlap determines how many males will gain access to mates (Altmann 1962). In several recent studies, the priority of access model has been shown to be a good predictor of the mating patterns of cercopithecine primates living in multimale groups during at least some periods of time (Bulger 1993; Weingrill et al. 2000; Alberts et al. 2003; Weingrill et al. 2003; Takahashi 2004; Setchell et al. 2005). Furthermore, when the priority of access model does not predict mating patterns, the model has provided a useful framework for understanding the dynamics of male-male competition (e.g. Hausfater 1975; 
Strum 1982; Alberts et al. 2003; Weingrill et al. 2003). The priority of access model has also proved useful in understanding male reproductive skew in other mammal species (e.g. Say et al. 2001; Engh et al. 2002).

We also know that high-ranking males monopolize reproduction more effectively when there are fewer males in the group (Cowlishaw \& Dunbar 1991; Bulger 1993; Alberts et al. 2003; but see also Weingrill et al. 2000). In savannah baboons, Papio cynocephalus, we know that high-ranking males experience mating advantages when their dominance rank is stable over longer periods and when coalitionary activity between males is limited (Alberts et al. 2003).

\section{Concordance between Mating Success and Paternity Success}

Mating success may not translate directly into paternity success if males differ in how successfully they parlay mating opportunities into conceptions. Differences between mating success and paternity success will indicate sexual selection for traits other than fighting ability, traits that affect the extent to which males can maintain or enhance, through to conception, the level of success they experience at mating. The relationship between mating and paternity is the focus of the current study.

Growing evidence from genetic analyses of paternity in primates indicates that high-ranking males do indeed often experience higher paternity success than lowranking males (reviewed in Di Fiore 2003). However, relatively little is known about the concordance between mating and paternity success in natural populations of primates, and even less is known about sources of variances in that concordance. We previously demonstrated that observed mating patterns were good predictors of the distribution of paternity during one 3-year period in one social group of Amboseli baboons (Papio cynocephalus; Altmann et al. 1996). However, our long-term study of the Amboseli population has taught us that patterns observed during one period or in one group may not be representative of all periods or groups, or even of the average condition. Furthermore, a number of studies have revealed a relatively poor correlation between observed mating patterns and offspring production; this has been reported both in primates, particularly captive or provisioned populations (Curie-Cohen et al. 1983; Stern \& Smith 1984; Berard et al. 1994), and in other large mammals (e.g. Pemberton et al. 1992; Coltman et al. 1999; Preston et al. 2001). Hence, it is important to establish whether mating predicts paternity as a general rule in our (or any other) study population. We tested this prediction over a 12-year period in a wild population of savannah baboons comprising seven social groups.

There are three reasons why observed mating behaviour might not accurately predict offspring production. (1) Behavioural records may be nonrepresentative of actual matings if some matings are surreptitious (decreasing the chance that they will be observed), (2) mating itself may be nonrandom if some males allocate more mating effort to periods of high fertility (so that the probability of conception is higher for some matings than for others) and (3) conception success may be nonrandom if sperm competition or sperm selection contribute to conception.

\section{Surreptitious copulations}

Surreptitious copulations have been reported in a range of vertebrate and invertebrate species, and in most species, this strategy tends to be adopted by relatively small or weak males (reviewed in Andersson 1994). In primate species with male rank precedence, we assume that most sneak copulations are performed by low-ranking males, so that the general effect of sneak copulation will be to decrease the paternity success of the highest-ranking males and increase the paternity success of lower-ranking males. For instance, among rhesus macaques, Macaca mulatta, living in the unusually high-density semicaptive population on Cayo Santiago, surreptitious copulations, especially by low-ranking males, were often observed, although these males produced fewer offspring than higher-ranking males that pursued a strategy of intensive mate guarding (Berard et al. 1994).

\section{Male mate choice}

Nonrandom mating will occur if some males use cues of female fertility to allocate mating effort to the females that are the most likely to conceive. The consequence will be that these males will be more likely, per mating, to produce offspring than will males that do not choose mates on this basis. What cues might males use? In many primate species, including baboons, females have exaggerated sexual swellings. Evidence from both captive and wild chimpanzees, Pan troglodytes (Emery \& Whitten 2003; Deschner et al. 2004) and from wild baboons (Gesquiere et al., in press) supports the hypothesis that changes in sexual swelling size and in sex hormone profiles provide potential cues for males about how likely it is that a given cycle will result in conception (see also Engelhardt et al. 2004). Furthermore, two different studies of chacma baboons, Papio ursinus, in southern Africa, and one study of chimpanzees in West Africa, have indicated that high-ranking males may indeed discriminate conceptive from nonconceptive cycles; that is, that they are more likely to mate-guard females experiencing conceptive cycles than those experiencing nonconceptive cycles (Bulger 1993; Weingrill et al. 2003; Deschner et al. 2004). This effect appeared to be limited to high-ranking males in each study, possibly reflecting the fact that these are the only males that can afford the opportunity cost of forgoing poorer-quality mating opportunities. That is, only highranking males have a high probability of obtaining a future mating opportunity if they forgo a current one. Therefore, if males are able to use fertility cues to identify females of higher fertility, we expect that the highestranking male in a group, the alpha male, will experience higher reproductive success than predicted based on his mating success. 


\section{Postcopulatory selection}

Postcopulatory selection may affect which male's sperm fertilizes the gamete of a female that mates multiply (Eberhard 1996; Birkhead \& Møller 1998; Birkhead \& Pizzari 2002). For instance, in Soay sheep, dominant males are highly successful in competing for access to and mating with fertile females, but as the mating season progresses, the sperm of these dominant males becomes relatively depleted and they lose in sperm competition to subordinate males, even though they continue to win in mating competition (Preston et al. 2001). In feral fowl, females preferentially eject the ejaculates of lower-ranking males, increasing the probability that their offspring will be sired by high-ranking males (Pizzari \& Birkhead 2000). In both examples, observed mating success does not accurately predict paternity success because mating success is just one of several successive stages of selection. In primates, sperm competition has had well-documented consequences for male morphology, physiology and behaviour (Gomendio et al. 1998). However, the processes of differential sperm success have been little studied in primates, and neither male-mediated nor female-mediated processes can be ruled out.

If sperm depletion occurs in primates, then the males that mate the most (typically the highest-ranking males) will generally have lower offspring production than expected based on mating success, as in Soay sheep (unless they also have higher sperm production, which does not appear to be the case in sheep, the only situation where it has been studied). The consequences of cryptic female choice are more difficult to predict. If cryptic female choice is directional (Birkhead \& Pizzari 2002), it should result in an increase in conception success for males of a given class or having a particular trait (e.g. high rank). However, nondirectional cryptic female choice (Birkhead \& Pizzari 2002) would not result in any predictable mismatch between mating and offspring production.

\section{Goals of this study}

We had two goals. Our first goal was to confirm that patterns of offspring production by males generally matched observed mating patterns in our study population (Altmann et al. 1996; Alberts et al. 2003). Specifically, do high-ranking males have an advantage, over long periods of time and changing demographic conditions, in offspring production as they do in mating? And, is variance in the offspring production of the highest-ranking male explained by the same factors that explain variance in mating success? Our second goal was to identify any difference between mating success and offspring production for males of different ranks, and to attempt to characterize the contributions of sneak copulation, male mate choice and sperm competition to male reproductive success in this species.

\section{METHODS}

\section{Study Subjects and Data Set}

This study was part of ongoing research into the biology of baboons in the Amboseli basin at the foot of Mt Kilimanjaro (e.g. Alberts \& Altmann 1995a; Altmann \&
Alberts 2003b). Study groups in this population are monitored on a near-daily basis and a variety of life history and behavioural information are collected, including data on mating and mate-guarding behaviour, agonistic behaviour for determining dominance, movements of males between groups, births and deaths.

We obtained genetic samples (primarily faecal samples) for 213 of 325 infants that were born into wild-feeding Amboseli study groups, Alto's and Hook's groups and their fission products (see Alberts et al. 2003; Altmann \& Alberts 2003b), between September 1988 (the earliest infants for which genetic samples were collected) and January 2001. Paternity was assigned for 208 of these infants (see Appendix). For some of the analyses described in this paper, we used all 208 paternity determinations. However, some of our analyses used restricted subsets of these 208 offspring. In particular, our analysis of the relationship between paternity, mate-guarding behaviour and dominance rank was confined to periods when (1) groups were relatively stable in membership and not undergoing fission events, (2) male dominance ranks were known unambiguously and (3) mating behaviour was intensively monitored (Table 1; see also Alberts et al. 2003). Specifically, this resulted in the exclusion of data from September 1988 to June 1996 for Alto's Group and its fission products, because from 1988 to 1991 Alto's Group was unstable in membership while undergoing fission, and from 1991 to June 1996 our monitoring of Alto's fission products involved reduced monitoring of mating and agonistic behaviour; we could not examine the relationship between behavioural measures and paternity success for this period. We also excluded Lodge Group (a study group that foraged part time at the refuse site of a tourist lodge) from our analysis (see also Alberts et al. 2003); results of an analysis of paternity in that group are reported elsewhere (Altmann et al. 1996).

\section{Behavioural and Life History Data}

\section{Male maturation and dominance rank}

Male baboons undergo testicular enlargement and hence are presumed capable of producing viable sperm (see Zinner et al. 2006) at a median age of 5.69 years in Amboseli (Alberts \& Altmann 1995b). At this stage males are considered to be subadults, because while they are physically capable of fertilizing females, their small size, relatively low normal sperm counts (Zinner et al. 2006)

Table 1. Study groups and time periods analysed in testing behavioural correlates of paternity and the priority of access model

\begin{tabular}{ll}
\hline Study group & \multicolumn{1}{c}{ Study period } \\
\hline Hook's & Sep 1988-Dec 1994 \\
Linda's (Hook's fission product) & Jan 1995-Jan 2001 \\
Weaver's (Hook's fission product) & Jan 1995-Jan 2001 \\
Nyayo's (Alto's fission product) & Jul 1996-Jan 2001 \\
Dotty's (Alto's fission product) & Jul 1996-Jul 1999 \\
Omo's (Dotty's fission product) & Aug 1999-Jan 2001 \\
Viola's (Dotty's fission product) & Aug 1999-Jan 2001 \\
\hline
\end{tabular}


and lack of ability to physically dominate adult males normally prevents them from gaining access to fertile females (Bercovitch 1986; Hamilton \& Bulger 1990; Alberts \& Altmann 1995b; Alberts et al. 2003). Male baboons experience rapid growth during subadulthood (Altmann \& Alberts 1987, 2005; Strum 1991; Johnson 2003; see also Shea 1990; Leigh 1992, 1995 for comparative data across primate species). We consider males to have attained adulthood when they begin to win agonistic interactions with adult males, which occurs at a median of 7.4 years in Amboseli (Alberts \& Altmann 1995b). Once males attain adulthood they typically rise rapidly in dominance rank (see also Hamilton \& Bulger 1990). They tend to disperse from the natal group before, or shortly after, attaining adult dominance rank (e.g. Packer 1979a; Hamilton \& Bulger 1990; Alberts \& Altmann 1995b), and they begin to mate-guard fertile females within a few months after attaining adulthood (Alberts \& Altmann 1995b). In Amboseli, males sometimes mate-guard extensively in the natal group (Alberts \& Altmann 1995a, b), but 94\% of the adult (as opposed to subadult) males in our study groups during this study were immigrant males (i.e. they had dispersed from their natal group and were reproductively active in non-natal groups).

Although subadult males perform virtually no mate guarding of fertile females (e.g. Hausfater 1975; Bercovitch 1986; Bulger 1993; Alberts et al. 2003), we included them as potential fathers in the genetic analysis because they are presumed capable of fathering offspring. We sought to determine whether males do actually produce any offspring in this life history stage in spite of their extremely limited mating success. However, we followed the general precedent in the literature and did not include subadult males in our analysis of the relationship between dominance rank and reproductive success. In this part of the analysis, we sought to determine the effects of dominance rank on offspring production. Because subadult males rank below all adult males and have very low mating success, including them in the analysis would artificially inflate the correlation between dominance rank and mating success (e.g. Bercovitch 1986, 1992).

Male dominance ranks were determined by assigning wins and losses in dyadic agonistic encounters between males, as described in Hausfater (1975). See Alberts et al. (2003) for a complete description and for a discussion of dominance rank as a measure of fighting ability. Male ages were assigned to all males as part of ongoing monitoring in this population. Ages were based on known birth dates for males born in study groups, or based on patterns of growth, maturation and change in physical parameters for immigrant males. Physical parameters used to estimate age included coat condition, degree of scarring, body carriage and canine tooth condition. Age scoring was developed by assessing known-age males and observing ageing patterns in long-term members of the population (see Alberts \& Altmann 1995a for details). Age and dominance rank are strongly correlated in baboons (Packer 1979a; Packer et al. 2000; Alberts et al. 2003). Typically, rank increases rapidly once males reach adulthood and peaks at around 8 years of age, both in Amboseli and in other well-studied populations (Packer 1979a; Hamilton \& Bulger 1990; Alberts et al. 2003).

\section{Female reproductive biology}

Female savannah baboons are sexually active during the follicular phase of the sexual cycle. After the first few days of this phase, the sex skin begins to swell (turgesce) and increases in volume until around the time of ovulation. During the luteal phase of the cycle the sex skin rapidly decreases in size (deturgesces) until it is flat. The 5-day period immediately prior to deturgesence of the sex skin is the period in which females are most likely to ovulate and conceive (Hendrickx \& Kraemer 1969; Wildt et al. 1977; Shaikh et al. 1982). Here we designate this period the 'ovulatory' phase of the cycle. Males often show interest in females much earlier in the follicular phase, beginning to mate-guard (consort with) them by closely following and preventing other males from gaining sexual access (e.g. Hall \& DeVore 1965; Hausfater 1975; Seyfarth 1978; Alberts et al. 1996; Gesquiere et al., in press; reviewed in Hrdy \& Whitten 1987; Dixson 1998). For the purpose of this study, analysis of the amount of mate-guarding time (i.e. of each female's total consort time) that males achieved was restricted to the 5-day ovulatory phase. We further restricted our analysis to ovulatory phases for which at least $5 \mathrm{~h}$ of behavioural mate-guarding data were available.

\section{Male paternity success by age and rank}

We counted the number of offspring assigned to each male (see Genetic Analysis and Paternity Determination for details on paternity assignment) and examined the distribution of paternity across males. We counted the total number of offspring that each male produced, and we also estimated the probability of offspring per conception opportunity as the total number of offspring that each male produced per conception opportunity, where a conception opportunity was defined as a conception for which the male in question was present in the group where the conception occurred. Thus, for instance, a male who was present for 10 conceptions and fathered 4 offspring had a higher proportion of conceptions per opportunity than a male who was present for 30 conceptions and produced 10 offspring.

To examine the relationship between male age class and paternity success, we assigned each offspring to a male age class depending upon the age of the father at that offspring's conception. Then, to get the number of offspring produced per male in each age class, we divided the total number of offspring produced by males in each age class by the number of males in those age classes available to father offspring. For example, to estimate number of offspring per male for age class 10, we summed all offspring that were conceived by males while they occupied age class 10 , and then divided that sum by the total number of males that were in age class 10 during all conceptions.

Similarly, to examine the relationship between male dominance rank and paternity success, we assigned each offspring to a male dominance rank position depending 
upon the rank of that offspring's father at the time of conception. Then, to measure the number of offspring produced per male for each rank position, we divided the total number of offspring produced by males in each rank position by the number of males of that rank. For example, to estimate the number of offspring per male for males of rank 5, we summed all offspring that were conceived by males while they occupied rank 5 , and then divided this sum by the number of conceptions for which rank position 5 was occupied (i.e. for which there were at least five males in the group).

To examine the relationship between male mating success and paternity success, we used the proportion of a female's consort time obtained by a male as our measure of mating success. This is a well-accepted measure of mating success in baboons because the large majority of copulations take place in the context of mate-guarding episodes (e.g. Packer 1979b; Bercovitch 1987; Bulger 1993; Alberts et al. 2003).

\section{The priority of access model}

The priority of access model (Altmann 1962) posits that male dominance rank functions as a queue in which males wait for mating opportunities, and that in the absence of queue-jumping (i.e. successful attempts by lower-ranking males to circumvent the queuing system), a male will be able to mate-guard a female only when all males that rank above him are already guarding mates. That is, when only one female in a group is fertile, the highest-ranked male will monopolize reproductive access to her (i.e. will perform all the mate guarding), when two females are fertile, the two highest-ranked males will monopolize mate guarding, and so on. For a male ranked 4 , for instance, there must be at least four adult females simultaneously fertile in order for him to mate-guard under the priority of access model. To assess the validity of the priority of access model, we counted, for every day of the ovulatory phase of each conceptive cycle of each mother in the study, the number of other females in the social group that were also in the ovulatory phase of their cycle. This allowed us to calculate the predicted proportion of mate guarding and the predicted proportion of offspring produced by males of different ranks. We then compared those predictions with the observed proportion of offspring actually produced and with the observed proportion of mate-guarding time that males of different rank achieved.

\section{Effects of density, rank stability and age differences}

To investigate the effects of male rank stability on paternity success, we defined 'stable periods' as those periods of time during which a single male continuously held the highest rank for at least 7 months, and in which multiple offspring had been conceived. The mean tenure of males at rank 1 was 8 months (see Appendix in Alberts et al. 2003), but defining stable periods by this criterion resulted in only four such periods being identified in which more than a few offspring were conceived. By setting the criterion for stable time periods at 7 instead of 8 months, we identified six such time periods, lasting 7-31 months.

To test the hypothesis that a high-ranking male's rank stability (the number of months that he continuously maintained rank 1) affected how well his observed paternity success fit the priority of access model, we calculated, for each of the six time periods described above, the sum of the absolute deviations between observed and expected number of offspring achieved for each rank position. We used this sum (a simple measure of the extent to which expected deviated from observed in each period) as the response variable in a linear model, where the predictor variable was the highest-ranking male's rank stability.

We also examined the effects of rank stability outside of these six relatively stable time periods. We restricted our analysis to the 81 conceptions in which only one female, the mother, was in the ovulatory phase of her cycle for the entire 5 days of that phase. These are situations in which the top-ranking male is predicted to completely monopolize mating, and hence conceptions, under the priority of access model. Consequently, instead of examining deviations from the priority of access model, we examined directly the relationship between rank stability and conception success in these situations.

To examine the effects of the number and age distribution of other males in the group, we again restricted our analysis to the conceptions that occurred when only one adult female, the mother, was in the ovulatory phase of her cycle for the entire 5 days of that phase. In all 81 of these conceptions, at least two adult males were present in the group at conception and male dominance ranks were known unambiguously; these conceptions were used to analyse the effects of male density on the paternity success of the highest-ranking male. In 78 of these conceptions, at least three adult males were in the group, and this subset was used to examine the effects of the mean age difference between the three highest-ranked males on the paternity success of the highest-ranking male.

\section{Statistical analyses}

We used simple linear regression to explore the relationship between opportunities for paternity and actual paternity (where an opportunity was defined as a conception for which a given male was present in the group), and to test the effect of rank stability on the success of the highest-ranking male. We used logistic regressions for all conception-by-conception analyses in which the response variable was paternity success versus failure on the part of the male(s) in question. We used the $G$ test for goodness of fit with the Williams correction (Sokal \& Rohlf 1995) to test whether the paternity success of males was predicted by their mating success.

\section{Genetic Analysis and Paternity Determination}

Methods for genetic analysis and paternity determination are described in detail in the Appendix (see also Buchan et al. 2003, 2005). Briefly, we obtained DNA for 
213 infants born in the study population between September 1988 and January 2001, 66 of their 78 different mothers, and 115 of the 126 different potential fathers for these offspring; note that a number of the infants also later occurred as mothers or fathers in the data set and so may appear in more than one of the categories listed above. We genotyped these animals at 12 tetranucleotide and two dinucleotide loci amplified with human primers. We used the multitubes approach (Navidi et al. 1992; Taberlet et al. 1996) and we used quantitative PCR to measure DNA concentrations in baboon faecal extracts before genotyping began, as recommended by Morin et al. (2001). We assigned paternity to 208 of the 213 offspring using both simple exclusion, and the program CERVUS 2.0 (Marshall et al. 1998). Our loci showed very good power for detecting paternity, and in every case our exclusionbased assignments agreed with assignments at 95\% confidence by CERVUS. Table A1 in the Appendix shows, for each of the 213 offspring, whether the mother was genotyped, the number of potential fathers genotyped, the number of potential fathers present in the group at the time, and the male that was assigned as the father. The 208 offspring for which we identified fathers represented $65 \%$ of the 325 offspring born in the population during the study period. There was no obvious systematic source of bias in the set of individuals for which we were able to assign paternity; they represented all the offspring that survived at least long enough for us to obtain a faecal sample. We assume here that these 208 offspring represented a sample of offspring that was random with respect to father's identity.

\section{RESULTS}

\section{Distribution of Paternity Among Males}

Males showed great variance in the number of offspring they produced. Of the 103 adult males that were present in a study group for at least one of the 208 conceptions for which paternity was assigned, only 53 (52\%) gained paternity. The number of offspring that these 53 males fathered ranged from 1 to 16 , with a mean of $3.87 \pm 0.46$ offspring per male (Table 2). All 208 offspring were fathered by males that lived in the mother's social group when they were conceived; we detected no evidence of extragroup paternity (Table A1; see Appendix for details of methods). Interestingly, 43 offspring, approximately $21 \%$, had at least one full sibling (16 sets of 2,1 set of 3 and 2 sets of 4 full siblings). From the perspective of full-sibship size, approximately $90 \%$ of the full sibships $(165 / 184)$ were of size one, $9 \%$ of size two and $1 \%$ greater than two.

The 103 males described above varied greatly in the number of conceptions for which they were present in the group, from 1 to 68 (Table 2). On average, the more conceptions a male was present for, the more offspring he produced. Twenty-nine per cent of the variance in paternity success was explained by variance in opportunities for paternity (i.e. by whether a male was in a study group when conceptions occurred there; $R_{\mathrm{adj}}^{2}=0.29, N=103$
Table 2. Paternity success for each adult male in the study. List is rank ordered by number of offspring fathered and then number of conceptions for which male was present

\begin{tabular}{|c|c|c|c|c|}
\hline $\begin{array}{l}\text { Count of } \\
\text { males }\end{array}$ & Male & $\begin{array}{l}\text { Number } \\
\text { of offspring } \\
\text { fathered* }^{*}\end{array}$ & $\begin{array}{l}\text { Number of } \\
\text { conceptions } \\
\text { for which male } \\
\text { was present* }\end{array}$ & $\begin{array}{c}\text { Percentage of } \\
\text { conceptions } \\
\text { that he } \\
\text { obtained }^{\star}\end{array}$ \\
\hline 1 & ROC & 16 & 38 & 42.1 \\
\hline 2 & AMI & 12 & 36 & 33.3 \\
\hline 3 & TUZ & 11 & 32 & 34.4 \\
\hline 4 & EDW & 9 & 42 & 21.4 \\
\hline 5 & $\mathrm{CHA}$ & 9 & 23 & 39.1 \\
\hline 6 & INZ & 9 & 14 & 64.3 \\
\hline 7 & ELF & 8 & 22 & 36.4 \\
\hline 8 & POW & 8 & 10 & 80.0 \\
\hline 9 & ALE & 7 & 31 & 22.6 \\
\hline 10 & AMA & 6 & 34 & 17.7 \\
\hline 11 & JIT & 6 & 28 & 21.4 \\
\hline 12 & PIS & 6 & 28 & 21.4 \\
\hline 13 & KEI & 6 & 27 & 22.2 \\
\hline 14 & PEP & 5 & 68 & 7.4 \\
\hline 15 & FEL & 5 & 27 & 18.5 \\
\hline 16 & NEP & 5 & 25 & 20.0 \\
\hline 17 & POL & 5 & 10 & 50.0 \\
\hline 18 & FAV & 4 & 44 & 9.1 \\
\hline 19 & GAS & 4 & 24 & 16.7 \\
\hline 20 & TYC & 4 & 21 & 19.1 \\
\hline 21 & PLA & 4 & 18 & 22.2 \\
\hline 22 & VAN & 4 & 8 & 50.0 \\
\hline 23 & MLO & 3 & 30 & 10.0 \\
\hline 24 & VEG & 3 & 29 & 10.3 \\
\hline 25 & DIS & 3 & 20 & 15.0 \\
\hline 26 & $\mathrm{GIZ}$ & 3 & 16 & 18.8 \\
\hline 27 & DEN & 2 & 30 & 6.7 \\
\hline 28 & $\mathrm{BEA}$ & 2 & 27 & 7.4 \\
\hline 29 & $\mathrm{NOL}$ & 2 & 26 & 7.7 \\
\hline 30 & ORB & 2 & 25 & 8.0 \\
\hline 31 & ORY & 2 & 24 & 8.3 \\
\hline 32 & $\mathrm{DHO}$ & 2 & 19 & 10.5 \\
\hline 33 & RUT & 2 & 19 & 10.5 \\
\hline 34 & IAG & 2 & 11 & 18.2 \\
\hline 35 & EXO & 2 & 10 & 20.0 \\
\hline 36 & ICA & 2 & 8 & 25.0 \\
\hline 37 & LOF & 2 & 4 & 50.0 \\
\hline 38 & ZIN & 2 & 4 & 50.0 \\
\hline 39 & ROY & 2 & 3 & 66.7 \\
\hline 40 & $\mathrm{GOL}$ & 1 & 50 & 2.0 \\
\hline 41 & NEL & 1 & 30 & 3.3 \\
\hline 42 & NOA & 1 & 23 & 4.4 \\
\hline 43 & NGG & 1 & 13 & 7.7 \\
\hline 44 & HNS & 1 & 7 & 14.3 \\
\hline 45 & FAT & 1 & 6 & 16.7 \\
\hline 46 & LIO & 1 & 6 & 16.7 \\
\hline 47 & YOY & 1 & 6 & 16.7 \\
\hline 48 & KER & 1 & 5 & 20.0 \\
\hline 49 & NYU & 1 & 5 & 20.0 \\
\hline 50 & KIL & 1 & 4 & 25.0 \\
\hline 51 & LIB & 1 & 2 & 50.0 \\
\hline 52 & SUJ & 1 & 1 & 100.0 \\
\hline 53 & ZAl & 1 & 1 & 100.0 \\
\hline 54 & SPY & 0 & 38 & 0.0 \\
\hline 55 & LEO & 0 & 33 & 0.0 \\
\hline 56 & MLI & 0 & 25 & 0.0 \\
\hline 57 & ZEN & 0 & 25 & 0.0 \\
\hline 58 & APH & 0 & 23 & 0.0 \\
\hline 59 & KAK & 0 & 22 & 0.0 \\
\hline 60 & HOB & 0 & 20 & 0.0 \\
\hline 61 & SHE & 0 & 19 & 0.0 \\
\hline 62 & ANU & 0 & 18 & 0.0 \\
\hline 63 & SEZ & 0 & 18 & 0.0 \\
\hline 64 & VEC & 0 & 15 & 0.0 \\
\hline
\end{tabular}


Table 2 (continued)

\begin{tabular}{|c|c|c|c|c|}
\hline $\begin{array}{l}\text { Count of } \\
\text { males }\end{array}$ & Male & $\begin{array}{l}\text { Number } \\
\text { of offspring } \\
\text { fathered* }^{*}\end{array}$ & $\begin{array}{l}\text { Number of } \\
\text { conceptions } \\
\text { for which male } \\
\text { was present* }\end{array}$ & $\begin{array}{c}\text { Percentage of } \\
\text { conceptions } \\
\text { that he } \\
\text { obtained* }\end{array}$ \\
\hline 65 & UDA & 0 & 13 & 0.0 \\
\hline 66 & DAL & 0 & 11 & 0.0 \\
\hline 67 & KIM & 0 & 11 & 0.0 \\
\hline 68 & KUS & 0 & 11 & 0.0 \\
\hline 69 & TIN & 0 & 11 & 0.0 \\
\hline 70 & SHY & 0 & 9 & 0.0 \\
\hline 71 & GOD & 0 & 8 & 0.0 \\
\hline 72 & GRE & 0 & 8 & 0.0 \\
\hline 73 & KAR & 0 & 8 & 0.0 \\
\hline 74 & PIU & 0 & 7 & 0.0 \\
\hline 75 & DES & 0 & 6 & 0.0 \\
\hline 76 & VUM & 0 & 6 & 0.0 \\
\hline 77 & IND & 0 & 5 & 0.0 \\
\hline 78 & KAD & 0 & 5 & 0.0 \\
\hline 79 & SUD & 0 & 4 & 0.0 \\
\hline 80 & $\mathrm{KHA}$ & 0 & 4 & 0.0 \\
\hline 81 & NAF & 0 & 4 & 0.0 \\
\hline 82 & PUT & 0 & 4 & 0.0 \\
\hline 83 & VIP & 0 & 4 & 0.0 \\
\hline 84 & ZAP & 0 & 4 & 0.0 \\
\hline 85 & HEN & 0 & 3 & 0.0 \\
\hline 86 & KWA & 0 & 3 & 0.0 \\
\hline 87 & LEM & 0 & 3 & 0.0 \\
\hline 88 & HYR & 0 & 2 & 0.0 \\
\hline 89 & ICO & 0 & 2 & 0.0 \\
\hline 90 & IPO & 0 & 2 & 0.0 \\
\hline 91 & PAS & 0 & 2 & 0.0 \\
\hline 92 & SAW & 0 & 2 & 0.0 \\
\hline 93 & UNG & 0 & 2 & 0.0 \\
\hline 94 & WAL & 0 & 2 & 0.0 \\
\hline 95 & DOB & 0 & 1 & 0.0 \\
\hline 96 & FRA & 0 & 1 & 0.0 \\
\hline 97 & LEW & 0 & 1 & 0.0 \\
\hline 98 & NAT & 0 & 1 & 0.0 \\
\hline 99 & NAY & 0 & 1 & 0.0 \\
\hline 100 & REX & 0 & 1 & 0.0 \\
\hline 101 & SPI & 0 & 1 & 0.0 \\
\hline 102 & TAL & 0 & 1 & 0.0 \\
\hline 103 & WIM & 0 & 1 & 0.0 \\
\hline
\end{tabular}

*Analysis was restricted to time periods when the male was adult; see Table A1 and text for information on three instances of offspring fathered by subadult males.

males, $P<0.0001$; Fig. 1). The relationship between opportunities and actual offspring produced was described by the equation $Y=0.122+0.128 X$, where $X$ is the number of conceptions for which the male was present; that is, a male produced on average approximately one additional offspring for each eight additional conceptions for which he was present. However, some males failed to produce offspring in spite of being present for a number of conceptions; of the 50 males in the analysis that fathered no offspring, 20 were present for eight or more conceptions, and 10 were present for 18 or more conceptions (Table 2). When we excluded from the analysis those males that produced no offspring, opportunity was still a significant predictor of offspring production, accounting for 19\% of the variance $\left(R_{\mathrm{adj}}^{2}=0.19, N=53\right.$ males, $\left.P<0.0006\right)$. A male that actually produced offspring produced on average one additional offspring for each nine additional

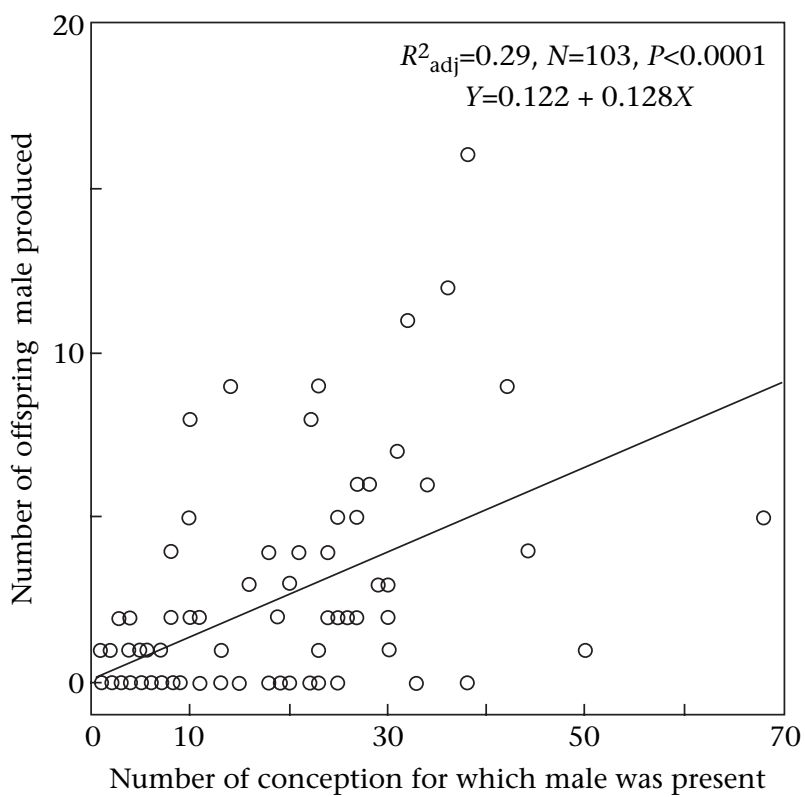

Figure 1. Number of offspring that each adult male produced as a function of the number of conceptions for which he was present as an adult.

conceptions for which he was present; the relationship between opportunities and actual offspring produced, for the subset of males that produced one or more offspring, was described by the equation $Y=1.68+0.108 X$.

A good deal of the variance in number of offspring produced was unaccounted for by opportunity alone; males obtained paternity for between 0\% and 100\% of the conceptions for which they were present (Table 2). We knew from previous work (Alberts et al. 2003) that a male's age and dominance rank affect mating success in this population, so we next examined the effects of these variables on paternity success.

\section{Paternity, Male Age and Male Dominance Rank}

The relationship between paternity and age was similar to that between rank and age (Fig. 2a). Mean number of offspring conceived per male rapidly increased between the ages of 7 and 9 years, peaked at 9 years of age and then gradually decreased with increasing age.

Male dominance rank was strongly related to paternity (Fig. 2b). Males in the highest rank position produced $60 \%$ more offspring than males in the second rank position and more than three times as many as males of rank 3 . Males lower than a dominance rank of 5 experienced a much sharper decline in paternity. This steep decline beyond rank 5 corresponded to the maximum number of females observed to have overlapping ovulatory phases in any given group during the study period (five females). The nonparametric Spearman coefficient for the correlation between rank and number of offspring per conception opportunity was $r_{\mathrm{S}}=0.85$ (data pooled over the entire study period for each rank position; $N=14$ rank positions; $P<0.0001)$; this was somewhat higher than 
(a)

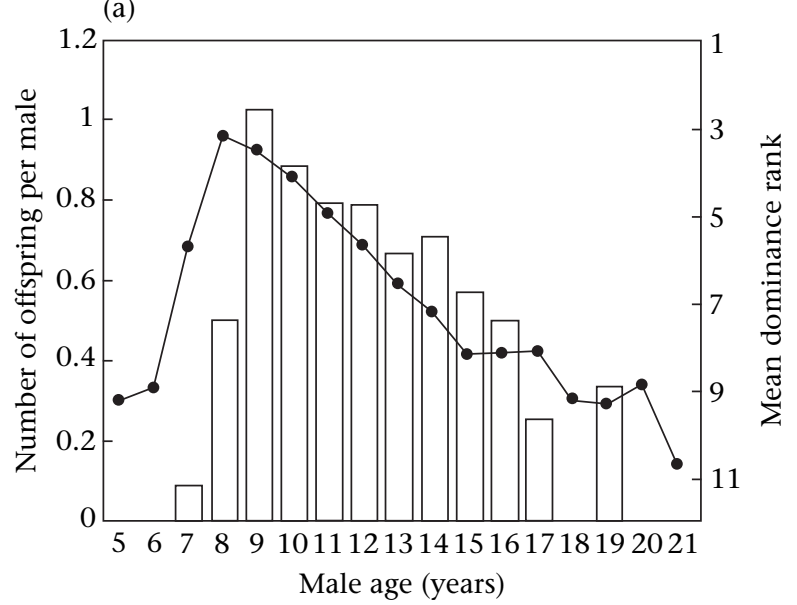

(b)

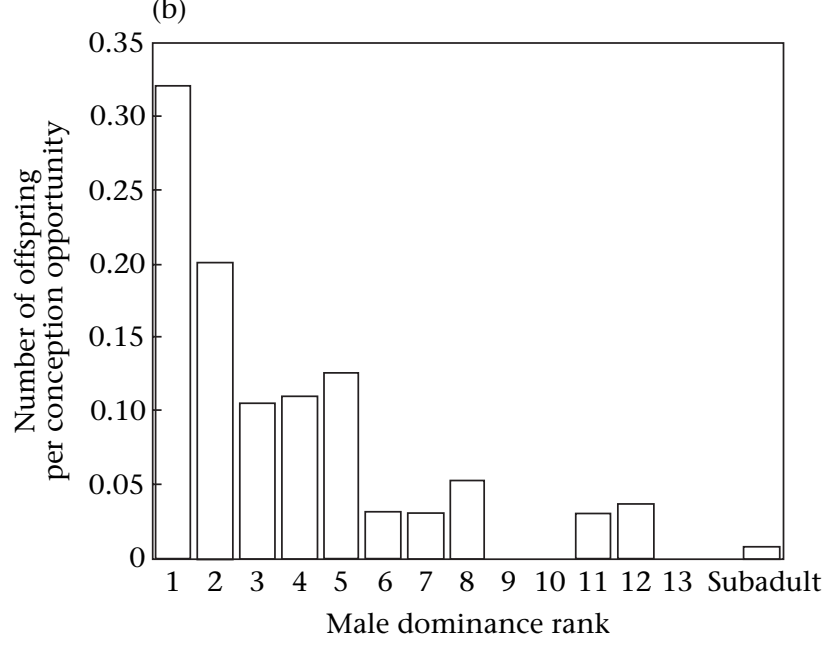

Figure 2. (a). Number of offspring produced per male $(\square)$ and mean dominance rank attained by males $(\bullet)$ in each age class. Total number of offspring produced by each age class was divided by the number of males in each age class that were present during conceptions. (b) Number of offspring per conception opportunity produced by males in each dominance rank position. Total number of offspring produced by males in each rank position was divided by the number of conceptions for which that rank position was occupied.

the mean correlation coefficient for the relationship between rank and mating success in this population (Alberts et al. 2003).

\section{Paternity by Subadult Males}

Although paternity was largely confined to adult males, three subadult males (out of 60 subadults in the study) sired one offspring each, accounting for approximately $1.5 \%$ of offspring genotyped. These three subadult males were all older subadults, within 5 months of attaining adulthood (see Methods and Alberts \& Altmann 1995b for criteria for adulthood versus subadulthood). In each case the conceptive female was multiparous. These three paternities attributed to subadults corresponded to 0.008 offspring per conception opportunity for all subadult males pooled, a value much lower than for most adult male rank positions (Fig. 2b).

In each case, the subadult male in question was maternally unrelated to the mother (i.e. they had had no common maternal relatives for at least four generations in two cases, and for at least three generations in the third case). We were unable to rule out the possibility of paternal relatedness in two of the three cases because we were not able to identify fathers for two of the three subadult males. In the third case, we were able to confirm that the subadult male in question was paternally, as well as maternally, unrelated to the mother of his offspring.

\section{Mate Guarding and Paternity}

Overall, the proportion of a female's consort time obtained by a male (his mating success, see Methods) was a good predictor of the likelihood of a male gaining paternity (logistic regression, chi-square approximation: $\chi_{1}^{2}=4.35, N=108$ conceptions, $P=0.0369$, with $5 \mathrm{~h}$ or more of observed mate guarding in the 5-day ovulatory period). This supports our previous findings that mating behaviour is a generally good predictor of paternity for wild male baboons (Altmann et al. 1996).

\section{Paternity and the Priority of Access Model}

The highest-ranked males obtained the largest proportion of paternity. However, with important exceptions (see below) they usually obtained far less paternity than predicted by the priority of access model (Fig. 3). A similar overall pattern has been described for mating success in this population (Alberts et al. 2003). For paternity success, as for mating success, the largest departure from the predictions of the priority of access model was for males ranked 1, alpha males. Whereas the model predicted that alpha males would father $84 \%$ of offspring, these males fathered $34 \%$ of offspring (49 of 145 offspring conceived during the periods of demographic stability identified in Table 1), and they obtained an even smaller proportion $(21 \%)$ of mate-guarding opportunities during these time periods (including both conceptive and nonconceptive cycles; see Fig. 3).

\section{Variance Over Time in the Fit to the Priority of Access Model}

We examined the six stable time periods in our data set (described in Methods) to examine variance over time in the fit to the priority of access model, and to measure the effects of rank stability on paternity success. Between 8 and 13 offspring were produced in each of these six time periods, for a total of 54 offspring. As with our earlier analysis of mating success (Alberts et al. 2003), we found that the fit of paternity to the priority of access model differed greatly in these six time periods (Fig. 4a-f), from a perfect fit for one male (Fig. 4a) to an extremely poor fit for three males (Fig. $4 \mathrm{~d}-\mathrm{f}$ ). 


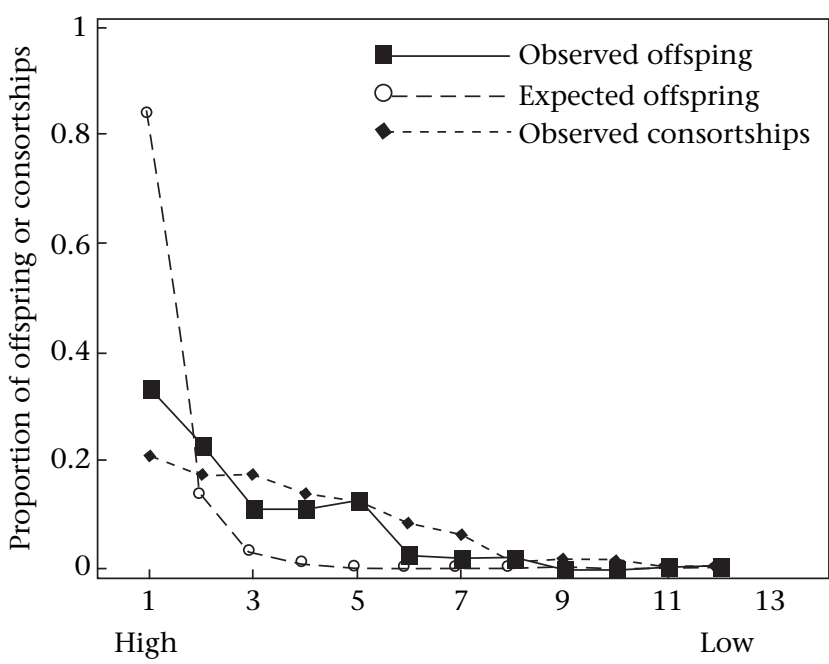

Male dominance rank

Figure 3. Observed and expected proportion of offspring produced by males of different dominance ranks, based on the priority of access model, and the observed proportion of consortships obtained.

\section{Effects of Rank Stability}

We found that longer periods of rank stability showed smaller deviations from the priority of access model. That is, during periods of greater rank stability, males achieved a closer fit to the priority of access model $\left(R_{\mathrm{adj}}^{2}=0.58\right.$, $N=6$ 'stable' time periods, $P=0.049$ ). We also found that the number of consecutive days that a male was ranked number 1 before a given conception significantly increased the likelihood that he gained paternity for that conception (logistic regression, chi-square approximation: $\chi_{1}^{2}=5.32, N=81$ conceptions that occurred when only one adult female, the mother, was in the ovulatory phase of her cycle for the entire 5 days of that phase, and adult male ranks were known unambiguously, $P=0.0211)$. In contrast to rank stability per se, the length of time the highest-ranking male had been present as an adult in the group before a given conception (regardless of his rank) had no significant effect on the likelihood of his gaining paternity during these situations (logistic regression, chi-square approximation: $\chi_{1}^{2}=0.039, N=81$ conceptions, $P=0.84$; all of the males in question were immigrant males, none were natal).

\section{Effects of Other Adult Males}

As expected, an increase in the number of adult males present in a group at the time of conception significantly reduced the probability of the dominant male gaining paternity (logistic regression, chi-square approximation: $\chi_{1}^{2}=33.31, \quad N=81$ conceptions, $P<0.0001$; see also

(d)
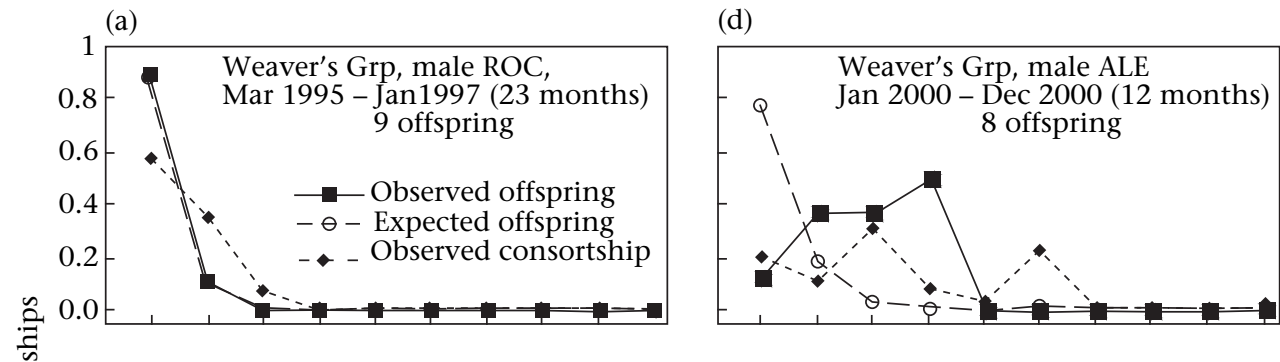

(e)

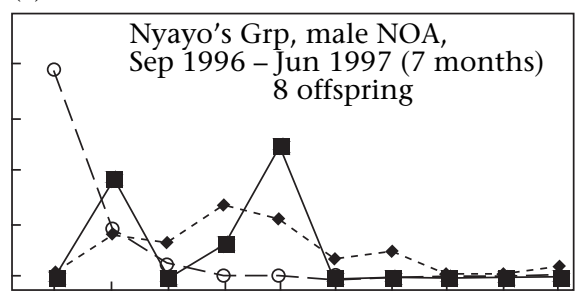

(f)

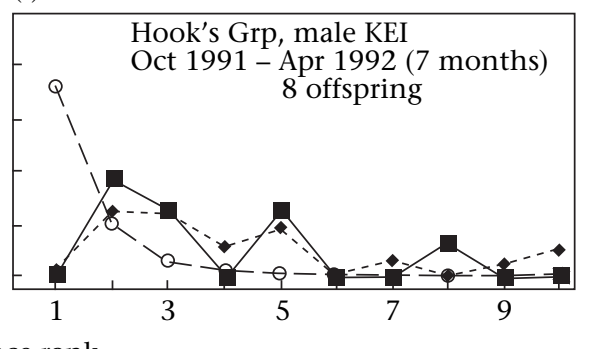

Figure 4. Variance in fit to the priority of access model. Observed and expected proportion of offspring produced and the observed proportion of consortships obtained by males in six time periods during which one male held rank 1 continuously for at least 7 months. 
Alberts et al. 2003 for similar results for mating success). However, we detected no significant effect of the mean age difference between the three highest-ranked males on whether the highest-ranking male obtained paternity (logistic regression, chi-square approximation: $\chi_{1}^{2}=2.49$, $N=78$ conceptions where at least three ranked males were present, $P=0.1146$ ). This result may be because the effect of age differences was relatively small compared to other effects, and would require a larger sample size to detect (Alberts et al. 2003).

\section{Elevated Paternity Success of High-ranking Males}

In spite of the fact that the proportion of mate-guarding time that a male obtained was a generally good predictor of his paternity success (see above), males of rank 1 (alpha males) produced more offspring (34\%) than expected based on the proportion of consort time that they obtained (21\%). We performed a $G$ test of goodness of fit for two classes, in which alpha males constituted one class and males of all other ranks pooled constituted the other class; expected values were based on the proportion of consort time that males of each class obtained. We found that alpha males produced significantly more offspring than expected based on how much consort time they obtained $\left(G_{\mathrm{adj}, 1}=204.85, P<0.0001\right)$.

This result suggested that alpha males were more likely to guard females on conceptive, rather than nonconceptive, cycles. To pursue this further, we examined the behaviour of males of different rank positions on days when more than one female was in the 5-day ovulatory phase of her cycle. In particular we focused on days on which at least one female was in the 5-day ovulatory phase of a nonconceptive cycle and at least one female was in that phase of a conceptive cycle. These situations presented males with a 'choice' of guarding a female that would conceive or not conceive. We counted the number of conceptive and nonconceptive cycles that were available on each day and then pooled across days to obtain the expected probability of a given male guarding conceptive versus nonconceptive females, based on the null hypothesis that males choose cycles at random (i.e. that they have no information about females' fertility status and/or that they do not exercise choice). We carried out binominal tests for males from rank 1 through 5 to determine whether males of any rank position guarded conceptive females more often than expected by chance.

We found that males of rank 1, alpha males, 'chose' a conceptive female to guard significantly more than expected by chance; they were expected to 'choose' conceptive females $48 \%$ of the time, but were observed to 'choose' conceptive females $71 \%$ of the time (binomial test: $Z=2.67, P=0.007$; Table 3 ). Males of ranks $2-5$ did not differ significantly in their expected and observed values. In other words, alpha males achieved higher conception rates than expected apparently because they exercised mate choice more effectively than did lower-ranking males. High-ranking males might exert mate choice in two different ways. First, they might discriminate against multiparous females that are experiencing nonconceptive cycles. Second, they might discriminate against adolescent females, which show lower fertility (conceive at a lower rate) than parous females (Scott 1984; Anderson 1986; Beehner et al. 2006; Gesquiere et al., in press). In particular, during their first four cycles after menarche, females very rarely have a guarding male accompanying them, but beginning in approximately their fifth cycle, they are guarded at rates similar to those of multiparous females (Gesquiere et al., in press). Females are also more than 10 times more likely to conceive after their first four cycles than during their first four cycles, although they still conceive at a lower rate than multiparous females (Gesquiere et al., in press).

To determine whether the excess paternity achieved by alpha males was because they avoided adolescent females more effectively than other males or because they avoided multiparous females that were experiencing nonconceptive cycles, we analysed the same data set described in the previous paragraph, but we excluded from consideration all cycles of adolescent females in their first four cycles after menarche. When we excluded these cycles (which were all nonconceptive cycles) from the analysis, we

Table 3. Observed and expected proportion of females' conceptive cycles that were mate-guarded by males of each rank

\begin{tabular}{|c|c|c|c|c|c|c|}
\hline $\begin{array}{l}\text { Male } \\
\text { dominance } \\
\text { rank }\end{array}$ & $\begin{array}{c}\text { Observed proportion } \\
\text { of conceptive cycles } \\
\text { guarded }\end{array}$ & $\begin{array}{c}\text { Expected } \\
\text { proportion } \\
\text { of conceptive cycles } \\
\text { guarded }\end{array}$ & $N$ & $\begin{array}{l}\text { Exact probability } \\
\text { based on binomial } \\
\text { distribution }\end{array}$ & $\begin{array}{l}Z \text { score (normal } \\
\text { approximation) }\end{array}$ & $\begin{array}{l}\text { Two-tailed } P \text { value } \\
\text { for } Z \text { score }\end{array}$ \\
\hline \multicolumn{7}{|c|}{ Including cycles of all females } \\
\hline 1 & 0.706 & 0.477 & 34 & 0.004 & 2.672 & 0.0075 \\
\hline 2 & 0.413 & 0.468 & 46 & 0.09 & -0.747 & 0.45 \\
\hline 3 & 0.462 & 0.429 & 26 & 0.15 & 0.336 & 0.73 \\
\hline 4 & 0.333 & 0.463 & 27 & 0.06 & -1.351 & 0.18 \\
\hline 5 & 0.542 & 0.465 & 24 & 0.12 & 0.753 & 0.45 \\
\hline \multicolumn{7}{|c|}{ Excluding cycles of females in adolescence } \\
\hline 1 & 0.593 & 0.494 & 27 & 0.09 & 1.03 & 0.30 \\
\hline 2 & 0.414 & 0.488 & 29 & 0.11 & -0.80 & 0.42 \\
\hline 3 & 0.625 & 0.442 & 16 & 0.07 & 1.48 & 0.14 \\
\hline 4 & 0.368 & 0.487 & 19 & 0.11 & -1.03 & 0.30 \\
\hline 5 & 0.500 & 0.476 & 14 & 0.21 & 0.18 & 0.85 \\
\hline
\end{tabular}


found that alpha males still guarded conceptive cycles more frequently than expected by chance (59\% observed, $49 \%$ expected), but this difference was no longer significant (exact binomial probability: $P=0.09 ; Z$ score for normal approximation: $Z=1.03, N=27$ 'choices' by males of rank 1 , one-tailed $P=0.15$; Table 3 ). As with the analysis including adolescent cycles, males of other ranks showed no significant deviations from expectations.

\section{DISCUSSION}

Males of any species will experience successive stages of sexual selection at each stage of reproduction. Their mode of locating females will experience sexual selection, as will their mode of gaining access to them (and their mode of preventing other males from doing so). They may experience selection to discriminate among females, allocating their mating efforts to the most fertile or highest-quality females, depending on whether the costs of doing so are offset by the benefits. They will experience intersexual selection for traits that females prefer, and in some species, males will experience selection to commit infanticide in order to increase the availability of fertile females. Finally, males will experience postmating selection, either through sperm competition or cryptic female choice. Here we focused on three of these successive stages of selection, (1) the stage of gaining access to females, (2) the stage of allocating mating effort and (3) the stage of postmating selection (sperm competition and selection). The other stages are all of potential interest in our study species, but will require different data sets to study.

The means by which males gain access to females has been studied in a very wide range of mammalian and nonmammalian taxa (reviewed in Andersson 1994), including many primates (reviewed in Cowlishaw \& Dunbar 1991; Di Fiore 2003). However, questions still remain for primates about the relative importance of various strategies for gaining access to females and about their effectiveness (reviewed in Di Fiore 2003). The stages of allocating mating effort and of postmating selection have received less attention in primates and in mammals generally, although their potential importance is certainly recognized and they have been extensively studied in some taxa (Andersson 1994; Eberhard 1996; Birkhead \& Møller 1998).

\section{Stage 1: Gaining Access to Females}

Clearly, for male baboons, as for many mammals, attaining high dominance rank is a major component of the solution to gaining access to females. Not only do high-ranking male baboons tend to obtain more mating opportunities, they also produce more offspring than do low-ranking males. This is a common, but not universal pattern in primates (Di Fiore 2003); variance in the relationship between rank and mating success occurs within populations, and within and between species, but most correlation coefficients are positive at all levels of analysis, both for mating success (Cowlishaw \& Dunbar 1991;
Bulger 1993; Alberts et al. 2003; Altmann \& Alberts 2003a) and for paternity success (Di Fiore 2003).

Male baboons live in close proximity to each other as well as to females, so gaining access to females also involves preventing other males from doing so; this is achieved by mate guarding. However, mate guarding is energy-limited and time consuming (Packer 1979b; Alberts et al. 1996), and it may be difficult for males to successfully mate-guard while they simultaneously feed themselves and fend off overt attacks from competitors. Inexperienced males in particular may have difficulty at this form of multitasking, and this may explain the fact that the peak in mean dominance rank occurs at an earlier age than the peak in offspring production (Fig. 2a; see also, e.g. Strum 1982).

Limited energy and/or experience may also make it difficult for guarding males to prevent sneak copulations by competing males. The relatively open habitat in Amboseli makes it difficult to conceal any activity from other group members, but sneak copulations, in which mating is rapid and appears furtive, with the male looking over his shoulder or scanning the group, are occasionally observed in our study population (personal observations), and are virtually always performed by subadult, not adult, males. Furthermore, our results suggest that such furtive matings by subadult males occasionally result in conception; three subadult males fathered offspring in our study, but in these three cases, the subadult fathers did not appear in our mating or mate-guarding records during the month in which they conceived these offspring (in fact, subadult males appear very infrequently in our mating records and rarely with fully fertile females; Alberts \& Altmann 1995a; Alberts et al. 2003). However, although sneak copulations may occasionally be successful, they probably result in little overall reproductive success for wild male baboons in open habitats such as Amboseli; subadults, the class most likely to use this strategy, produced on average only one offspring in 125 conception opportunities. In contrast, observed mate guarding (nonsurreptitious mating) was in general a good predictor of paternity in this study (see also Engelhardt et al. 2006). Sneak copulations may be more effective in forest settings, or in the high-density, high-fertility settings typical of captive and semicaptive populations. However, even in these latter populations (where it has been systematically studied) it does not appear to be as effective as mate guarding (Berard et al. 1994).

\section{Stage 2: Allocating Mating Effort}

Seventy per cent of the sexual cycles of multiparous female baboons are nonconceptive (Gesquiere et al., in press); that is, the female has a complete and apparently normal sexual cycle and mates repeatedly but does not conceive an offspring (interestingly, this value of $70 \%$ reflects a fecundability not dissimilar to women in industrialized societies, for whom median time to conception is between two and three cycles, reflecting a higher than $50 \%$ rate of cycling without conception; Tuntiseranee et al. 1998; Axmon \& Hagmar 2005). The frequency of 
nonconceptive cycles is much higher for adolescent female baboons (Gesquiere et al., in press). Should males discriminate against these nonconceptive cycles? On the one hand, it is relatively uncommon for more than one female to be in the ovulatory phase of the sexual cycle at any one time (see priority of access expectations in Bulger 1993; Weingrill et al. 2000; Alberts et al. 2003; Weingrill et al. 2003; this study). This means that even if a given cycle represents a low probability of conception, males are not forgoing other mating opportunities by pursuing it. On the other hand, mate guarding is energetically expensive (Packer 1979b; Alberts et al. 1996), and if males lose energy reserves during mate guarding, they may be in a poor position to take advantage of the next opportunity that arises. Males that can correctly identify which mating opportunities to forgo will experience an advantage over males that mate indiscriminately.

Do males differentiate conceptive from nonconceptive cycles? For at least three species with exaggerated sexual swellings, chimpanzees, longtailed macaques and baboons, evidence suggests that they do (Bulger 1993; Emery \& Whitten 2003; Weingrill et al. 2003; Deschner et al. 2004; Engelhardt et al. 2004; Gesquiere et al., in press); in all these studies, alpha males discriminated in favour of conceptive cycles. Our results support these observations and indicate that this discrimination translates in higher offspring production than expected based on time allocated to mate guarding. In other words, avoiding adolescent females is a major mechanism of mate choice by which alpha males, but not males of other ranks, increase their paternity success. This result also suggests that alpha males may discriminate amongst parous females of differing fertility, but at best this effect is weaker than the effect of avoiding adolescents, and a larger sample size will be required to test it definitively (see Gesquiere et al., in press).

\section{Stage 3: Postmating Selection}

Our results do not support the hypothesis that sperm competition via sperm depletion or differential sperm quantity plays a direct role in differential paternity success for male baboons; males that mated the most produced the most offspring, unlike dominant male Soay sheep (Preston et al. 2001). Similarly with respect to cryptic female choice, observed mate-guarding time was in general a good predictor of offspring production (see also Buchan et al. 2003), making it unlikely that cryptic female choice contributes to postmating selection. The primary exception to the concordance between mating success and paternity success was reflected in the higher-than-expected reproductive success of alpha males compared to their mating success. While we suggest that this occurs because high-ranking males exert mate choice, we cannot rule out the possibility that it reflects cryptic female choice that favours the sperm of high-ranking males. Patterns of sperm precedence may also influence paternity success, although no data support this possibility in primates, and proximity to ovulation is more likely to be important than order of mating over the sexual cycle (Dixson 1998).
More detailed data on mating episodes and outcomes will be required to test the possibility that cryptic female choice contributes to conception success of male baboons (e.g. see Engelhardt et al. 2006).

\section{Conclusions}

Male baboons, like many primates (and many mammals), show obvious male-male competition and have pronounced weapons (their canines) and large body size. Consequently, research on sexual selection in these species has usually focused on the stage of gaining access to mates, and in particular on fighting ability. This has resulted in an archetypal view of males of most primate species, a view in which males are primarily selected for fighting. However, researchers have long understood that sexual selection must be acting on many traits of male primates. An early focus of interest was intersexual selection, and the propensity for males to pursue friendships with females as an alternative route to gaining access to mating opportunities (e.g. Strum 1982, 1994; Smuts 1985). Another focus has been on the ability of males to form complex social alliances with other males aimed at overthrowing dominant males (e.g. Packer 1977; Bercovitch 1988; Noë 1992; Noë \& Sluijter 1995), and yet another has been the remarkable tendency for males to kill the offspring of other males (Hrdy 1979; Hrdy \& Whitten 1987; Janson \& van Schaik 2000). More recently, growing evidence supports the notion that male primates show mate choice, discriminating in favour of highfertility mating opportunities (Bulger 1993; Weingrill et al. 2003; Deschner et al. 2004; this study). Finally, recent evidence indicates that male primates protect and care for their own offspring even in multimale groups in which females mate multiply (Palombit et al. 1997; Borries et al. 1999; Buchan et al. 2003). Because of these various research efforts, the archetypal image of the male primate selected for fighting is developing into a more nuanced view of an animal that not only fights to gain access to mating opportunities, but engages in complex social relationships with conspecifics of both sexes, allocates mating effort carefully whenever possible, and invests in offspring care. As research on sexual selection in primates expands, an even more complex picture of male primates will undoubtedly emerge.

\section{Acknowledgments}

This work was supported by the National Science Foundation (IOB-0322613, IOB-0322781, BCS-0323553, NSF BCS-0323596), the Chicago Zoological Society and Duke University. We thank the Office of the President, Republic of Kenya, the Kenya Wildlife Services, its Amboseli staff and Wardens, the Institute for Primate Research, the National Museums of Kenya, and the members of the Amboseli-Longido pastoralist communities. Particular thanks go to the Amboseli fieldworkers who contributed to genetic sampling and data collection, especially R.S. Mututua, S. Sayialel, and J.K. Warutere. Russ Van Horn provided helpful comments on the manuscript. Laurence 
Gesquiere helped with the male mate choice analysis. Karen Drysdale provided extensive and able database assistance, and Caroline Inazu provided help with manuscript preparation. All protocols were noninvasive and complied with relevant regulations in Kenya (Kenya Research Permit MOEST 13/001/33C 179) and the U.S.A. (Duke University Institutional Animal Care and Use Committee protocol A180-03-05).

\section{References}

Alberts, S. C. \& Altmann, J. 1995a. Balancing costs and opportunities: dispersal in male baboons. American Naturalist, 145 , 279-306.

Alberts, S. C. \& Altmann, J. 1995b. Preparation and activation: determinants of age at reproductive maturity in male baboons. Behavioral Ecology and Sociobiology, 36, 397-406.

Alberts, S. C., Altmann, J. \& Wilson, M. L. 1996. Mate guarding constrains foraging activity of male baboons. Animal Behaviour, 51, 1269-1277.

Alberts, S. C., Watts, H. E. \& Altmann, J. 2003. Queuing and queue-jumping: long-term patterns of reproductive skew in male savannah baboons, Papio cynocephalus. Animal Behaviour, 65, 821-840.

Altmann, S. A. 1962. A field study of the sociobiology of rhesus monkeys, Macaca mulatta. Annals of the New York Academy of Sciences, 102, 338-435.

Altmann, J. \& Alberts, S. C. 2003a. Variability in reproductive success viewed from a life-history perspective in baboons. American Journal of Human Biology, 15, 401-409.

Altmann, J. \& Alberts, S. C. 2003b. Intraspecific variability in fertility and offspring survival in a nonhuman primate: behavioral control of ecological and social sources. In: Offspring: Human Fertility Behavior in Biodemographic Perspective (Ed. by K. W. Wachter \& R. A. Bulatao), pp. 140-169. Washington, D.C.: National Academies Press.

Altmann, J. \& Alberts, S. C. 2005. Growth rates in a wild primate population: ecological influences and maternal effects. Behavioral Ecology and Sociobiology, 57, 490-501.

Altmann, J. \& Alberts, S. 1987. Body mass and growth rates in a wild primate population. Oecologia, 72, 15-20.

Altmann, J., Alberts, S. C., Haines, S. A., Dubach, J., Muruthi, P., Coote, T., Geffen, E., Cheesman, D. J., Mututua, R. S., Saiyalel, S. N., Wayne, R. K., Lacy, R. C. \& Bruford, M. W. 1996. Behavior predicts genetic structure in a wild primate group. Proceedings of the National Academy of the Sciences, U.S.A., 93, 5797-5801.

Anderson, C. M. 1986. Female age, male preference and reproductive success in primates. International Journal of Primatology, 7, 305-326.

Andersson, M. 1994. Sexual Selection. Princeton, New Jersey: Princeton University Press.

Axmon, A. \& Hagmar, L. 2005. Time to pregnancy and pregnancy outcome. Fertility and Sterility, 84, 966-974.

Beehner, J. C., Onderdonk, D. A., Alberts, S. C. \& Altmann, J. 2006. The ecology of conception and pregnancy failure in wild baboons. Behavioural Ecology, 17, 741-750.

Berard, J. D., Nurnberg, P., Epplen, J. T. \& Schmidtke, J. 1994. Alternative reproductive tactics and reproductive success in male rhesus macaques. Behaviour, 129, 177-200.

Bercovitch, F. B. 1986. Male rank and reproductive activity in savanna baboons. International Journal of Primatology, 7, 533-550.

Bercovitch, F. B. 1987. Reproductive success in male savanna baboons. Behavioral Ecology and Sociobiology, 21, 163-172.

Bercovitch, F. B. 1988. Coalitions, cooperation and reproductive tactics among adult male baboons. Animal Behaviour, 36, 1198-1209.
Bercovitch, F. B. 1992. Re-examining the relationship between rank and reproduction in male primates. Animal Behaviour, 44, 1168-1170.

Birkhead, T. R. \& Møller, A. P. 1998. Sperm Competition and Sexual Selection. San Diego: Academic Press.

Birkhead, T. R. \& Pizzari, T. 2002. Postcopulatory sexual selection. Nature Reviews Genetics, 3, 262-273.

Borries, C., Launhardt, K., Epplen, C., Epplen, J. T. \& Winkler, P. 1999. Males as infant protectors in Hanuman langurs (Presbytis entellus) living in multimale groups: defence pattern, paternity and sexual behaviour. Behavioral Ecology and Sociobiology, 46, 350-356.

Buchan, J. C., Alberts, S. C., Silk, J. B. \& Altmann, J. 2003. True paternal care in a multi-male primate society. Nature, 425, 179-181.

Buchan, J. C., Archie, E. A., Van Horn, R. C., Moss, C. J. \& Alberts, S. C. 2005. Locus effects and sources of error in noninvasive genotyping. Molecular Ecology Notes, 5, 680-683.

Bulger, J. B. 1993. Dominance rank and access to estrous females in male savanna baboons. Behaviour, 127, 67-103.

Clutton-Brock, T. H., Guinness, F. E. \& Albon, S. D. 1982. Red Deer: Behavior and Ecology of Two Sexes. Chicago: University of Chicago Press.

Coltman, D. W., Bancroft, D. R., Robertson, A., Smith, J. A., Clutton-Brock, T. H. \& Pemberton, J. M. 1999. Male reproductive success in a promiscuous mammal: behavioural estimates compared with genetic paternity. Molecular Ecology, 8, 11991209.

Cowlishaw, G. \& Dunbar, R. I. M. 1991. Dominance rank and mating success in male primates. Animal Behaviour, 41, 1045-1056.

Curie-Cohen, M., Yoshihara, D., Luttrell, L., Benafordo, K., MacCluer, J. W. \& Stone, W. H. 1983. The effects of dominance on mating behavior and paternity in a captive troop of rhesus monkeys (Macaca mulatta). American Journal of Primatology, 5, 127-138.

Deschner, T., Heistermann, M., Hodges, K. \& Boesch, C. 2004. Female sexual swelling size, timing of ovulation, and male behavior in wild West African chimpanzees. Hormones and Behavior, 46, 204-215.

Di Fiore, A. 2003. Molecular genetic approaches to the study of primate behavior, social organization, and reproduction. Yearbook of Physical Anthropology, 46, 62-99.

Dixson, A. F. 1998. Primate Sexuality: Comparative Studies of the Prosimians, Monkeys, Apes and Human Beings. Oxford: Oxford University Press.

Eberhard, W. G. 1996. Female Control: Sexual Selection by Cryptic Female Choice. Princeton, New Jersey: Princeton University Press.

Emery, M. A. \& Whitten, P. L. 2003. Size of sexual swellings reflects ovarian function in chimpanzees (Pan troglodytes). Behavioral Ecology and Sociobiology, 54 (4), 340-351.

Engelhardt, A., Pfeifer, A. B., Heistermann, M., Niemitz, C., Van Hooff, J. \& Hodges, J. K. 2004. Assessment of female reproductive status by male longtailed macaques, Macaca fascicularis, under natural conditions. Animal Behaviour, 67, 915-924.

Engelhardt, A., Heistermann, M., Hodges, J. K., Nurnberg, P. \& Niemitz, C. 2006. Determinants of male reproductive success in wild long-tailed macaques (Macaca fascicularis): male monopolisation, female mate choice or post-copulatory mechanisms? Behavioral Ecology and Sociobiology, 59, 740-752.

Engh, A. L., Funk, S. M., Van Horn, R. C., Cribner, K. T., Bruford, M. W., Libants, S., Szykjam, M., Smale, L. \& Holekamp, K. E. 2002. Reproductive skew among males in a female-dominated mammalian society. Behavioral Ecology, 13, 193-200.

Gesquiere, L. R., Wango, E. O., Alberts, S. C. \& Altmann, J. In press. Mechanisms of sexual selection: sexual swellings and estrogen concentrations as fertility indicators and cues for male consort decisions in wild baboons. Hormones and Behavior. 
Gomendio, M., Harcourt, A. H. \& Roldan, E. R. S. 1998. Sperm competition in mammals. In: Sperm Competition and Sexual Selection (Ed. by T. R. Birkhead \& A. P. Møller), pp. 667-756. San Diego: Academic Press.

Hall, K. R. L. \& DeVore, I. 1965. Baboon social behavior. In: Primate Behavior (Ed. by I. DeVore), pp. 53-110. New York: Holt, Rinehardt \& Winston.

Hamilton, W. J., III \& Bulger, J. B. 1990. Natal male baboon rank rises and successful challenges to resident alpha males. Behavioral Ecology and Sociobiology, 26, 357-362.

Hausfater, G. 1975. Dominance and Reproduction in Baboons (Papio cynocephalus). Basel: Karger.

Hendrickx, A. G. \& Kraemer, D. C. 1969. Observations on the menstrual cycle, optimal mating time and pre-implantation embryos of the baboon, Papio anubis and Papio cynocephalus. Journal of Reproductive Fertility, Supplement, 6, 119-128.

Hrdy, S. B. 1979. Infanticide among animals: review, classification, and examination of the implications for the reproductive strategies of females. Ethology and Sociobiology, 1, 13-40.

Hrdy, S. B. \& Whitten, P. L. 1987. Patterning of sexual activity. In: Primate Societies (Ed. by B. B. Smuts, D. L. Cheney, R. M. Seyfarth, R. W. Wrangham \& T. T. Struhsaker), pp. 370-384. Chicago: University of Chicago Press.

Janson, C. H. \& van Schaik, C. P. 2000. The behavioral ecology of infanticide by males. In: Infanticide by Males and Its Implications (Ed. by C. P. van Schaik \& C. P. Janson), pp. 469-494. Cambridge: Cambridge University Press.

Johnson, S. E. 2003. Life history and the competitive environment: trajectories of growth, maturation, and reproductive output among chacma baboons. American Journal of Physical Anthopology, 120, 83-98.

LeBoeuf, B. J. 1974. Male-male competition and reproductive success in elephant seals. American Zoologist, 14, 163-176.

Leigh, S. R. 1992. Patterns of variation in the ontogeny of primate body size dimorphism. Journal of Human Evolution, 23, 27-50.

Leigh, S. R. 1995. Socioecology and the ontogeny of sexual size dimorphism in anthropoid primates. American Journal of Physical Anthopology, 97, 339-356.

Marshall, T. C., Slate, J., Kruuk, L. E. B. \& Pemberton, J. M. 1998. Statistical confidence for likelihood-based paternity inference in natural populations. Molecular Ecology, 7, 639-655.

Moore, N. P., Kelly, P. F., Cahill, J. P. \& Hayden, T. J. 1995. Mating strategies and mating success of fallow (Dama dama) bucks in a non-lekking population. Behavioral Ecology and Sociobiology, 36, 91-100.

Morin, P. A., Chambers, K. E., Boesch, C. \& Vigilant, L. 2001. Quantitative polymerase chain reaction analysis of DNA from noninvasive samples for accurate microsatellite genotyping of wild chimpanzees (Pan troglodytes verus). Molecular Ecology, 10, 1835-1844.

Navidi, W., Arnheim, N. \& Waterman, M. S. 1992. A multipletubes approach for accurate genotyping of very small DNA samples by using PCR: statistical considerations. American Journal of Human Genetics, 50, 347-359.

Noë, R. 1992. Alliance formation among male baboons: shopping for profitable partners. In: Coalitions and Alliances in Animals and Humans (Ed. by A. H. Harcourt \& F. B. M. de Waal), pp. 284321. Oxford: Oxford University Press.

Noë, R. \& Sluijter, A. A. 1995. Which adult male savanna baboons form coalitions? International Journal of Primatology, 16, 77-105.

Packer, C. 1977. Reciprocal altruism in Papio anubis. Nature, 265, 441-443.

Packer, C. 1979a. Inter-troop transfer and inbreeding avoidance in Papio anubis. Animal Behaviour, 27, 1-36.
Packer, C. $1979 \mathrm{~b}$. Male dominance and reproductive activity in Papio anubis. Animal Behaviour, 27, 37-45.

Packer, C., Collins, D. A. \& Eberly, L. E. 2000. Problems with primate sex ratios. Philosophical Transactions of the Royal Society of London, Series B, 355, 1627-1635.

Palombit, R. A., Seyfarth, R. M. \& Cheney, D. L. 1997. The adaptive value of friendships to female baboons: experimental and observational evidence. Animal Behaviour, 54, 599-614.

Pemberton, J. M., Albon, S. D., Guinness, F. E., Clutton-Brock, T. H. \& Dover, G. 1992. Behavioral estimates of male mating success tested by DNA fingerprinting in a polygynous mammal. Behavioral Ecology, 3, 66-75.

Pizzari, T. \& Birkhead, T. R. 2000. Female feral fowl eject sperm of subdominant males. Nature, 405, 787-789.

Poole, J. H. 1989. Mate guarding, reproductive success and female choice in African elephants. Animal Behaviour, 37, 842-849.

Preston, B. T., Stevenson, I. R., Pemberton, J. M. \& Wilson, K. 2001. Dominant rams lose out by sperm production. Nature, 409, 681-682.

Say, L., Pontier, D. \& Natoli, E. 2001. Influence of oestrus synchronization on male reproductive success in the domestic cat (Felis catus L.). Proceedings of the Royal Society of London, Series B, 268, 1049-1053.

Scott, L. M. 1984. Reproductive behavior of adolescent female baboons (Papio anubis) in Kenya. In: Female Primates: Studies by Women Primatologists (Ed. by M. F. Small), pp. 77-100. New York: A.R. Liss.

Setchell, J. M., Charpentier, M. \& Wickings, E. J. 2005. Mate guarding and paternity in mandrills: factors influencing alpha male monopoly. Animal Behaviour, 70, 1105-1120.

Seyfarth, R. M. 1978. Social relationships among adult male and female baboons. II. Behaviour throughout the female reproductive cycle. Behaviour, 64, 227-247.

Shaikh, A. A., Celaya, C. L., Gomez, I. \& Shaikh, S. A. 1982. Temporal relationship of hormonal peaks to ovulation and sex skin deturgescence in the baboon. Primates, 23, 444-452.

Shea, B. T. 1990. Dynamic morphology: growth, life history, and ecology in primate evolution. In: Primate Life History and Evolution (Ed. by C. J. DeRousseau), pp. 325-352. New York: Wiley-Liss.

Smuts, B. B. 1985. Sex and Friendship in Baboons. Hawthorn, New York: Aldine.

Sokal, R. R. \& Rohlf, F. J. 1995. Biometry. New York: W.H. Freeman.

Stern, B. R. \& Smith, D. G. 1984. Sexual behaviour and paternity in three captive groups of rhesus monkeys (Macaca mulatta). Animal Behaviour, 32, 23-32.

Strum, S. C. 1982. Agonistic dominance in male baboons: an alternative view. International Journal of Primatology, 3, 175-202.

Strum, S. C. 1991. Weight and age in wild olive baboons. American Journal of Primatology, 25, 219-237.

Strum, S. C. 1994. Reconciling aggression and social manipulation as means of competition. 1. Life-history perspective. International Journal Of Primatology, 15, 739-765.

Taberlet, P., Griffin, S., Goossens, B., Questiau, S., Manceau, V., Escaravage, N., Waits, L. P. \& Bouvet, J. 1996. Reliable genotyping of samples with very low DNA quantities using PCR. Nucleic Acids Research, 24, 3189-3194.

Takahashi, H. 2004. Do males have a better chance of mating when the number of estrous females is equal to or greater than the males' ordinal rank? Testing the hypothesis in Japanese macaques. American Journal of Primatology, 63, 95-102.

Tuntiseranee, P., Olsen, J., Chongsuvivatwong, V. \& Limbutara, S. 1998. Fecundity in Thai and European regions: results based on waiting time to pregnancy. Human Reproduction, 13, 471477. 
Weingrill, T., Lycett, J. E. \& Henzi, S. P. 2000. Consortship and mating success in chacma baboons (Papio cynocephalus ursinus). Ethology, 106, 1033-1044.

Weingrill, T., Lycett, J. E., Barrett, L., Hill, R. A. \& Henzi, S. P. 2003. Male consortship behaviour in chacma baboons: the role of demographic factors and female conceptive probabilities. Behaviour, 140, 405-427.

Wildt, D. E., Doyle, L. L., Stone, S. C. \& Harrison, R. M. 1977. Correlation of perineal swelling with serum ovarian hormone levels, vaginal cytology, and ovarian follicular development during the baboon reproductive cycle. Primates, 18, 261-270.

Zinner, D., Krebs, E., Schrod, A. \& Kaumanns, W. 2006. Early sexual maturity in male hamadryas baboons (Papio hamadryas hamadryas). American Journal of Physical Anthropology, 129, 584-590.

\section{Appendix: Genetic Analysis}

\section{Sample collection and DNA extraction}

DNA was obtained for 329 individuals, including 213 infants born in the study population between September 1988 and January 2001, 66 of 78 mothers and 115 of 126 potential fathers of these offspring; because our study spanned 12 years, some individuals appeared both as offspring and as mothers or fathers in our sample. Table A1 shows, for each offspring, whether the mother was sampled, the number of potential fathers present in the social group at conception (including subadult males), and the number of these males that were genotyped.

Faeces were the primary source of DNA (259 individuals). Blood samples were obtained when baboons were darted and anaesthetized for other purposes (67 individuals) and tissue samples were obtained from a few animals whose carcasses were located after they died of natural causes (3 individuals).

Fresh faeces were collected as soon as possible (within seconds or minutes) after animals of known identity were observed to defecate. In the large majority of cases, multiple independent faecal samples were collected for each individual. Approximately $2 \mathrm{~g}$ of faeces were collected from the leading end of the faecal bolus and placed in a vial containing $10 \mathrm{ml}$ of $95 \%$ ethanol. Samples were stored for up to 6 months at ambient temperature in the field before being stored at $-80^{\circ} \mathrm{C}$ in the laboratory. Most samples were a few months to several years old at the time of extraction.

The QIAamp DNA Stool Mini Kit (Qiagen, Valencia, California, U.S.A.) was used to extract DNA from faeces, with modifications as described in Buchan et al. (2003). Tissue and blood samples were extracted with a standard phenol/chloroform extraction or the DNeasy Tissue Kit (Qiagen).

\section{Quantification of DNA}

Quantitative (or 'real time') PCR was used to measure DNA concentrations in baboon faecal extracts before genotyping began, as recommended by Morin et al. (2001). Quantitative PCRs were carried out in $25-\mu 1$ reactions containing $1 \times$ Amplitaq Gold Buffer II, $0.5 \mu \mathrm{M}$ of 6-ROX, $3.5 \mathrm{mM}$ of $\mathrm{MgCl}_{2}, 800 \mathrm{nM}$ of dNTPs, $300 \mathrm{nM}$ of each primer, $100 \mathrm{nM}$ of probe, $2.5 \mu \mathrm{g}$ of BSA, 1.25 units of Amplitaq Gold DNA polymerase (Applied Biosystems Foster City, California) and $2 \mu \mathrm{l}$ of DNA extract. Amplifications were performed in a two-stage reaction consisting of an initial denaturation of $95^{\circ} \mathrm{C}$ for $10 \mathrm{~min}$ followed by 45 cycles of $95^{\circ} \mathrm{C}$ for $15 \mathrm{~s}$ and $59^{\circ} \mathrm{C}$ for $30 \mathrm{~s}$. All assays were carried out in an ABI Prism 7000 Sequence Detector (Applied Biosystems), and analysis was performed using the ABI Prism 7000 Sequence Detector software, versions 1.0 and 1.1. Quantification was conducted using standards of $20 \mathrm{ng}, 5 \mathrm{ng}, 1.25 \mathrm{ng}, 312.6 \mathrm{pg}, 78.2 \mathrm{pg}$ and $19.6 \mathrm{pg}$ in $2 \mu \mathrm{l}$, generated by serial dilution of an ABI $10 \mathrm{ng} / \mu \mathrm{l}$ standard (TaqMan Central Genomic DNA, product number 4312660).

\section{Microsatellite amplification}

All baboons were genotyped at 12 tetranucleotide and two dinucleotide microsatellite loci amplified with human primers (Buchan et al. 2005). No reactions were multiplexed. With the exception of two loci, all microsatellites were located on different chromosomes to avoid potential linkage problems. At one locus (D13s159) a high frequency of null alleles was suspected. The primers for this locus were redesigned (D13s159BF, aca cct ctc cca gtt gtt gg, D13s159BR, caa ctc cag gcc aaa tca tc) and all apparently homozygous individuals were genotyped again with the new primers.

Reactions were carried out in $12.5-\mu$ l reactions containing $1 \times$ Amplitaq Gold Buffer II, between 1 and $2 \mathrm{mM}$ of $\mathrm{MgCl}_{2}, 0.2 \mathrm{mM}$ of dNTPs, $0.2 \mu \mathrm{M}$ of each primer, $1.25 \mu \mathrm{g}$ of BSA, 0.5 units of Amplitaq Gold DNA polymerase (Applied Biosystems) and $1 \mu \mathrm{l}$ of faecal DNA extract. PCRs were carried out on an Eppendorf Mastercycler. Thirteen of the 14 loci were amplified using an initial denaturation of $95^{\circ} \mathrm{C}$ for $10 \mathrm{~min}, 16$ cycles of $95^{\circ} \mathrm{C}$ for $15 \mathrm{~s}, 66^{\circ} \mathrm{C}$ $\left(-1^{\circ} \mathrm{C}\right.$ per cycle) for $30 \mathrm{~s}, 72^{\circ} \mathrm{C}$ for $30 \mathrm{~s}$, followed by 29 cycles of $95^{\circ} \mathrm{C}$ for $15 \mathrm{~s}, 50^{\circ} \mathrm{C}$ for $30 \mathrm{~s}, 72^{\circ} \mathrm{C}$ for $30 \mathrm{~s}$, and a single final extension at $72^{\circ} \mathrm{C}$ for $3 \mathrm{~min}$. For locus D5s1457 the thermal cycle differed in that the initial annealing temperature began at $60^{\circ} \mathrm{C}$ and the final annealing steps were carried out at $44^{\circ} \mathrm{C}$.

\section{Assigning genotypes}

We used a modified version of the multitubes approach (Navidi et al. 1992; Taberlet et al. 1996). Initially, two replicate positive PCRs were carried out for each individual at each locus. In cases where Mendelian mother-offspring checks could not be carried out (i.e. when we genotyped adult males whose mothers were not known, or when we genotyped animals whose mothers had died before sampling), we attempted to carry out two initial replicates from two independent faecal samples (i.e. two independent defecations by the same individual).

Results of the two initial replicate positive PCRs allowed individuals to be classified in one of three ways at each locus. (1) Individuals were categorized as 'confirmed heterozygotes' if both PCRs produced identical heterozygote genotypes and no Mendelian mismatches. (2) Individuals were categorized as 'possible heterozygotes' if the first two PCRs produced both a heterozygote and homozygote genotype with a common allele between 
them, or two genotypes that were each homozygous for a different allele. (3) Individuals were categorized as possible homozygotes if both initial replicates revealed a single, identical allele. Further replication depended on these classifications. For confirmed heterozygotes, no further replications were performed. Possible heterozygotes were replicated until both alleles were observed at least twice. If one of the alleles observed in the initial replicates failed to appear again, it was classified as an error and the individual was reclassified as a possible homozygote.

Our class of possible homozygotes resolved into two classes, confirmed homozygotes, and heterozygotes that initially appeared as homozygotes because of allelic dropout, the failure of amplification of one allele of a heterozygote, a common problem with degraded DNA (e.g. Taberlet et al. 1996; Morin et al. 2001). Our procedure for resolving these cases depended on the quantity of template DNA in the sample; in this respect we followed a modified version of the protocol recommended by Morin et al. (2001). For extracts with less than $200 \mathrm{pg} / \mu \mathrm{l}$ of template, possible homozygotes were considered confirmed homozygotes if the same, single allele was observed in a total of seven PCRs. If an additional allele appeared two or more times in those replicates, the individual was considered a heterozygote. If an additional allele appeared only once, the individual was considered a homozygote and the unique allele was labelled an error.

For extracts with greater than $200 \mathrm{pg} / \mu \mathrm{l}$ of template, possible homozygotes were replicated a total of four times and if no further alleles were observed it was considered a confirmed homozygote; this is a conservative modification of the recommendation given by Morin et al. (2001). If a second allele was observed, then further replications were carried out and the genotype was determined using the same rules as for extracts with less than $200 \mathrm{pg} /$ $\mu \mathrm{l}$ of template.

\section{Paternity analysis via exclusion}

Paternity was based on exclusion and further supported through the use of the likelihood-based paternity assignment program CERVUS 2.0 (Marshall et al. 1998). For the exclusion analysis, we assigned paternity to a male if he could not be excluded at a minimum of 13 of the 14 loci, and if all other males were excluded at multiple loci. For 164 of 213 offspring, all potential fathers were sampled; for the remaining 49 offspring, one $(N=30)$, two $(N=17)$ or three $(N=2)$ potential fathers were not sampled (Table A1). In all but one of these cases, a single sampled male matched the offspring at all loci and all other sampled males were excluded at multiple loci; we assigned paternity to the single sampled male that was not excluded, and assumed that the father was not an unsampled male. In one case, all sampled males were excluded at a minimum of eight loci, and paternity was assigned to the unsampled male (see Table A1).

In addition to standard exclusion analysis, exclusion was also carried out using only heterozygous genotypes to determine whether paternity was being based solely on mismatches involving homozygotes that may have been the result of undetected allelic dropout. Removing all homozygous genotypes from the analysis did not change the conclusion of the paternity analysis with the exception of two offspring for which the number of males that could not be excluded at all (heterozygous) loci increased from one to two.

\section{Paternity analysis using CERVUS 2.0}

Likelihood-based paternity analysis was carried out with the rate of error set at three different levels (1\%, 5\% and $10 \%)$ to investigate the robustness of the paternity analysis to the possibility of higher-than-expected error. The following values were used in the paternity simulation: 10 candidate males (the average number of males present at conception), 96.8\% males sampled, $99.6 \%$ of loci typed and 10000 simulation cycles.

To investigate the possible occurrence of extragroup paternity, we also ran a CERVUS analysis in which all sampled subadult and adult males that were present in the entire population at the time of conception (not just the offspring's social group) were considered as potential fathers for each infant. When all males in the population at the time of conception were considered, the following parameters were used in the paternity simulation: 53 candidate males (the average number of males present in the population at the time of conception), $70 \%$ of candidate males sampled, $99.6 \%$ of loci typed, $1 \%$ error and 10000 cycles. Levels of confidence for all CERVUS analyses were set at $95 \%$ and $80 \%$.

Paternity was assigned for 208 of the 213 offspring for which samples were available (Table A1). For 201 of these offspring, paternity was unambiguous; that is, one male could not be excluded at any of the 14 loci and all other sampled males were excluded at multiple loci. However, for six of the remaining seven offspring for which paternity was assigned, one male was excluded at a single locus and all other males were excluded at multiple loci. In each of these six cases, CERVUS assigned paternity to the male that was excluded at a single locus, and did so with a high degree of confidence (95\%). As a result, we accepted these males as the true fathers and concluded that the observed exclusions were due to mutation or unresolved genotyping errors. For the remaining one offspring, all sampled males were excluded at multiple loci and CERVUS did not assign paternity to any male in the population with high confidence (Table A1). In this case we assigned paternity to the one unsampled male in the group (see paternity analysis via exclusion, above).

\section{Concordance among paternity analyses}

There was a high level of agreement between exclusion and likelihood-based paternity assignment for these 208 offspring. Furthermore, in 203 of 208 cases, CERVUS assigned the same male paternity under all conditions $(1 \%, 5 \%$ and $10 \%$ error, with all males in population considered). In four of the remaining five cases, CERVUS assigned different males as fathers (with lower confidence) when higher error rates were assumed; we accepted the assignment that assumed the lowest error rate, which in all cases agreed with our exclusion analysis. In one case, 
CERVUS was unable to identify a father with $95 \%$ confidence under any condition; this was the case described above, in which all sampled males in the population were excluded at multiple loci and the sole unsampled male from that group and time, whom we eventually assigned as the father, was known to be resident in the group at the time of conception.

Paternity could not be assigned for five of 213 offspring (Table A1). Two offspring (DEL and LAL) did not share alleles with their mothers at several loci. These discrepancies were probably a result of incorrect identification of offspring faecal samples, as the two mothers involved
(DUD and LIM), shared alleles at all loci with four and six other offspring, respectively. For the remaining three offspring (PES, SIT and WIK), CERVUS did assign paternity with a high level of certainty under at least some conditions, but we did not accept these assignments. In one case (PES), the mother was not sampled, the offspring was genotyped at only 6 of 14 loci because of technical difficulties, and all sampled potential fathers could be excluded at one or more loci. For one offspring, SIT, two males (NOL and POL) could not be excluded and for another offspring, WIK, all sampled males in the population were excluded at four or more loci.

Table A1. Paternity analysis results

\begin{tabular}{|c|c|c|c|c|c|c|c|c|c|c|}
\hline \multirow[b]{2}{*}{ Count } & \multirow[b]{2}{*}{ Mother } & \multirow[b]{2}{*}{ Offspring } & \multirow[b]{2}{*}{$\begin{array}{c}\text { Mother } \\
\text { sampled? }\end{array}$} & \multirow{2}{*}{$\begin{array}{c}\text { Number of } \\
\text { potential fathers } \\
\text { (number genotyped) }\end{array}$} & \multirow[b]{2}{*}{$\begin{array}{c}\text { Concensus } \\
\text { father }\end{array}$} & \multirow{2}{*}{$\begin{array}{l}\text { Male excluded } \\
\text { at fewest loci } \\
\text { (number of loci } \\
\text { excluded at) }\end{array}$} & \multicolumn{4}{|c|}{ \% Error } \\
\hline & & & & & & & 1 & 5 & 10 & $\begin{array}{l}\text { All males in } \\
\text { population } \ddagger\end{array}$ \\
\hline 1 & KEL & KIW & $Y$ & $9(9)$ & ALE & ALE (0) & ALE* $^{*}$ & $\mathrm{ALE}^{*}$ & $\mathrm{ALE}^{*}$ & $\mathrm{ALE}^{*}$ \\
\hline 2 & LAS & LEE & $Y$ & $10(10)$ & ALE & ALE (0) & ALE* $^{*}$ & ALE* $^{*}$ & ALE* $^{*}$ & ALE* \\
\hline 3 & LAZ & LOB & $\mathrm{Y}$ & $11(11)$ & ALE & ALE (1) & ALE* $^{*}$ & $\mathrm{ALE}^{*}$ & $\mathrm{ALE}^{*}$ & ALE* \\
\hline 4 & LIM & LYE & $Y$ & $10(10)$ & ALE & ALE (0) & ALE* $^{*}$ & $\mathrm{ALE}^{*}$ & ALE* $^{*}$ & ALE* $^{*}$ \\
\hline 5 & LUN & LOG & $Y$ & 11(11) & ALE & ALE (0) & ALE* $^{*}$ & $\mathrm{ALE}^{*}$ & ALE* $^{*}$ & ALE* \\
\hline 6 & LUN & LYM & $\mathrm{Y}$ & $14(14)$ & ALE & ALE (0) & ALE* $^{*}$ & $\mathrm{ALE}^{*}$ & $\mathrm{ALE}^{*}$ & ALE* $^{*}$ \\
\hline 7 & WEN & WEB & $Y$ & $7(7)$ & ALE & ALE (0) & $\mathrm{ALE}^{*}$ & $\mathrm{ALE}^{*}$ & $\mathrm{ALE}^{*}$ & $\mathrm{ALE}^{*}$ \\
\hline 8 & ASH & $A C A$ & $\mathrm{Y}$ & 9(9) & AMA & AMA (0) & $\mathrm{AMA}^{*}$ & $\mathrm{AMA}^{*}$ & $\mathrm{AMA}^{*}$ & $\mathrm{AMA}^{*}$ \\
\hline 9 & KEL & KEY & $Y$ & $14(14)$ & AMA & AMA (0) & $\mathrm{AMA}^{*}$ & $\mathrm{AMA}^{*}$ & $\mathrm{AMA}^{*}$ & $\mathrm{AMA}^{*}$ \\
\hline 10 & VEL & VOW & $Y$ & $8(8)$ & AMA & AMA (0) & $\mathrm{AMA}^{*}$ & $\mathrm{AMA}^{*}$ & $\mathrm{AMA}^{*}$ & $\mathrm{AMA}^{*}$ \\
\hline 11 & VET & VIG & $Y$ & $12(12)$ & AMA & AMA (0) & $\mathrm{AMA}^{*}$ & $\mathrm{AMA}^{*}$ & $\mathrm{AMA}^{*}$ & $\mathrm{AMA}^{*}$ \\
\hline 12 & WAG & WYN & $\mathrm{Y}$ & $11(11)$ & AMA & AMA (0) & $\mathrm{AMA}^{*}$ & $\mathrm{AMA}^{*}$ & $\mathrm{AMA}^{*}$ & $\mathrm{AMA}^{*}$ \\
\hline 13 & WEA & WRI & $Y$ & $11(11)$ & AMA & AMA (0) & $\mathrm{AMA}^{*}$ & $\mathrm{AMA}^{*}$ & $\mathrm{AMA}^{*}$ & $\mathrm{AMA}^{*}$ \\
\hline 14 & CEL & CED & $\mathrm{Y}$ & $9(8)$ & AMI & AMI (0) & $\mathrm{AMI}^{*}$ & $\mathrm{AMI}^{*}$ & $\mathrm{AMI}^{*}$ & $\mathrm{AMI}^{*}$ \\
\hline 15 & DUD & DRA & $\mathrm{Y}$ & $10(10)$ & AMI & AMI (0) & $\mathrm{AMI}^{*}$ & $\mathrm{AMI}^{*}$ & $\mathrm{AMI}^{*}$ & $\mathrm{AMI}^{*}$ \\
\hline 16 & DUD & DYN & $Y$ & $14(14)$ & AMI & AMI (0) & $\mathrm{AMI}^{*}$ & $\mathrm{AMI}^{*}$ & $\mathrm{AMI}^{*}$ & $\mathrm{AMI}^{*}$ \\
\hline 17 & FUM & FAR & $Y$ & $9(9)$ & AMI & AMI (0) & $\mathrm{AMI}^{*}$ & $\mathrm{AMI}^{*}$ & $\mathrm{AMI}^{*}$ & $\mathrm{AMI}^{*}$ \\
\hline 18 & FUM & FAS & $Y$ & 13(13) & AMI & AMI (0) & $\mathrm{AMI}^{*}$ & $\mathrm{AMI}^{*}$ & $\mathrm{AMI}^{*}$ & $\mathrm{AMI}^{*}$ \\
\hline 19 & $\mathrm{HAL}$ & HUM & $Y$ & $8(7)$ & AMI & AMI (0) & $\mathrm{AMI}^{*}$ & $\mathrm{AMI}^{*}$ & $\mathrm{AMI}^{*}$ & $\mathrm{AMI}^{*}$ \\
\hline 20 & HEK & $\mathrm{HON}$ & $Y$ & $12(12)$ & AMI & AMI (0) & $\mathrm{AMI}^{*}$ & $\mathrm{AMI}^{*}$ & $\mathrm{AMI}^{*}$ & $\mathrm{AMI}^{*}$ \\
\hline 21 & HEL & HIC & $Y$ & $13(13)$ & AMI & AMI (0) & $\mathrm{AMI}^{*}$ & $\mathrm{AMI}^{*}$ & $\mathrm{AMI}^{*}$ & $\mathrm{AMI}^{*}$ \\
\hline 22 & NYA & NIK & $\mathrm{Y}$ & $13(13)$ & AMI & AMI (0) & $\mathrm{AMI}^{*}$ & $\mathrm{AMI}^{*}$ & $\mathrm{AMI}^{*}$ & $\mathrm{AMI}^{*}$ \\
\hline 23 & NYA & NYL & $\mathrm{Y}$ & $8(8)$ & AMI & AMI (0) & $\mathrm{AMI}^{*}$ & $\mathrm{AMI}^{*}$ & $\mathrm{AMI}^{*}$ & $\mathrm{AMI}^{*}$ \\
\hline 24 & SER & SOK & $\mathrm{Y}$ & $12(12)$ & AMI & AMI (0) & $\mathrm{AMI}^{*}$ & $\mathrm{AMI}^{*}$ & $\mathrm{AMI}^{*}$ & $\mathrm{AMI}^{*}$ \\
\hline 25 & FED & FLA & $Y$ & $10(9)$ & AMI & AMI (1) & $\mathrm{AMI}^{*}$ & $\mathrm{AMI}^{*}$ & $\mathrm{AMI}^{*}$ & $\mathrm{AMI}^{*}$ \\
\hline 26 & LAZ & LEB & $\mathrm{Y}$ & $5(5)$ & BEA & BEA (0) & $\mathrm{BEA}^{*}$ & $\mathrm{BEA}^{*}$ & $\mathrm{BEA}^{*}$ & $\mathrm{BEA}^{*}$ \\
\hline 27 & LUN & $\mathrm{LOZ}$ & $Y$ & $5(5)$ & BEA & BEA (0) & $\mathrm{BEA}^{*}$ & $\mathrm{BEA}^{*}$ & $\mathrm{BEA}^{*}$ & $\mathrm{BEA}^{*}$ \\
\hline 28 & LAD & LIW & $Y$ & $4(4)$ & $\mathrm{CHA}$ & $\mathrm{CHA}(0)$ & $\mathrm{CHA}^{*}$ & $\mathrm{CHA}^{*}$ & $\mathrm{CHA}^{*}$ & $\mathrm{CHA}^{*}$ \\
\hline 29 & LIN & LOL & $Y$ & $4(4)$ & $\mathrm{CHA}$ & $\mathrm{CHA}(0)$ & $\mathrm{CHA}^{*}$ & $\mathrm{CHA}^{*}$ & $\mathrm{CHA}^{*}$ & $\mathrm{CHA}^{*}$ \\
\hline 30 & MYS & MUF & $Y$ & $4(4)$ & $\mathrm{CHA}$ & $\mathrm{CHA}(0)$ & $\mathrm{CHA}^{*}$ & $\mathrm{CHA}^{*}$ & $\mathrm{CHA}^{*}$ & $\mathrm{CHA}^{*}$ \\
\hline 31 & $\mathrm{NIG}$ & NJU & $Y$ & $6(6)$ & $\mathrm{CHA}$ & $\mathrm{CHA}(0)$ & $\mathrm{CHA}^{*}$ & $\mathrm{CHA}^{*}$ & $\mathrm{CHA}^{*}$ & $\mathrm{CHA}^{*}$ \\
\hline 32 & NYO & NOD & $\mathrm{Y}$ & $5(5)$ & $\mathrm{CHA}$ & $\mathrm{CHA}(0)$ & $\mathrm{CHA}^{*}$ & $\mathrm{CHA}^{*}$ & $\mathrm{CHA}^{*}$ & $\mathrm{CHA}^{*}$ \\
\hline 33 & WAS & WAB & $Y$ & $4(4)$ & $\mathrm{CHA}$ & $\mathrm{CHA}(0)$ & $\mathrm{CHA}^{*}$ & $\mathrm{CHA}^{*}$ & $\mathrm{CHA}^{*}$ & $\mathrm{CHA}^{*}$ \\
\hline 34 & WAS & WIZ & $\mathrm{Y}$ & $4(4)$ & $\mathrm{CHA}$ & $\mathrm{CHA}(0)$ & $\mathrm{CHA}^{*}$ & $\mathrm{CHA}^{*}$ & $\mathrm{CHA}^{*}$ & $\mathrm{CHA}^{*}$ \\
\hline 35 & WEM & WIV & $Y$ & $6(6)$ & $\mathrm{CHA}$ & $\mathrm{CHA}(0)$ & $\mathrm{CHA}^{*}$ & $\mathrm{CHA}^{*}$ & $\mathrm{CHA}^{*}$ & $\mathrm{CHA}^{*}$ \\
\hline 36 & NYO & NYM & $Y$ & 4(4) & $\mathrm{CHA}$ & $\mathrm{CHA}(1)$ & $\mathrm{CHA}^{*}$ & $\mathrm{CHA}^{*}$ & $\mathrm{CHA}^{*}$ & $\mathrm{CHA}^{*}$ \\
\hline 37 & LIM & LOC & $Y$ & $14(13)$ & DEN & DEN (0) & DEN* & DEN* & DEN* & DEN* \\
\hline 38 & PEN & PUM & $\mathrm{N}$ & $14(14)$ & DEN & DEN (0) & DEN* & DEN* & DEN* & DEN* \\
\hline 39 & HAM & $\mathrm{HAJ}$ & $Y$ & $15(15)$ & $\mathrm{DHO}$ & $\mathrm{DHO}(0)$ & DHO* & DHO* & DHO* & DHO* \\
\hline 40 & SOU & SCE & $Y$ & $13(13)$ & $\mathrm{DHO}$ & $\mathrm{DHO}(0)$ & DHO* & DHO* & DHO* & DHO* \\
\hline 41 & LAM & LEW & $\mathrm{N}$ & $15(15)$ & DIS & DIS (0) & DIS* & DIS* & DIS* & DIS* \\
\hline 42 & LIN & LIO & $Y$ & $16(16)$ & DIS & DIS (0) & DIS* & DIS* & DIS* & DIS* \\
\hline 43 & PRU & POW & $Y$ & $14(14)$ & DIS & DIS (0) & DIS* & DIS* & DIS* & DIS* \\
\hline 44 & ASH & $A B B$ & $Y$ & $12(12)$ & EDW & $\operatorname{EDW}(0)$ & EDW* & $\mathrm{EDW}^{*}$ & EDW* & $\mathrm{EDW}^{*}$ \\
\hline 45 & $\mathrm{CHE}$ & CAI & $Y$ & $8(8)$ & EDW & $\operatorname{EDW}(0)$ & EDW* & $\mathrm{EDW}^{*}$ & $\mathrm{EDW}^{*}$ & $\mathrm{EDW}^{*}$ \\
\hline 46 & $\mathrm{CHE}$ & $\mathrm{COB}$ & $Y$ & $10(9)$ & EDW & $\operatorname{EDW}(0)$ & EDW* & EDW* & $\mathrm{EDW}^{*}$ & $\mathrm{EDW}^{*}$ \\
\hline 47 & DRO & DUX & $Y$ & $8(7)$ & EDW & $\operatorname{EDW}(0)$ & EDW* & EDW* & $\mathrm{EDW}^{*}$ & $\mathrm{EDW}^{*}$ \\
\hline 48 & FED & $\mathrm{FIG}$ & $\mathrm{Y}$ & $13(13)$ & EDW & EDW (0) & $\mathrm{EDW}^{*}$ & $\mathrm{EDW}^{*}$ & EDW* & $\mathrm{EDW}^{*}$ \\
\hline
\end{tabular}


Table A1 (continued)

\begin{tabular}{|c|c|c|c|c|c|c|c|c|c|c|}
\hline \multirow[b]{2}{*}{ Count } & \multirow[b]{2}{*}{ Mother } & \multirow[b]{2}{*}{ Offspring } & \multirow[b]{2}{*}{$\begin{array}{c}\text { Mother } \\
\text { sampled? }\end{array}$} & \multirow{2}{*}{$\begin{array}{c}\text { Number of } \\
\text { potential fathers } \\
\text { (number genotyped) }\end{array}$} & \multirow[b]{2}{*}{$\begin{array}{c}\text { Concensus } \\
\text { father }\end{array}$} & \multirow{2}{*}{$\begin{array}{l}\text { Male excluded } \\
\text { at fewest loci } \\
\text { (number of loci } \\
\text { excluded at) }\end{array}$} & \multicolumn{4}{|c|}{ \% Error } \\
\hline & & & & & & & 1 & 5 & 10 & $\begin{array}{l}\text { All males in } \\
\text { population }\end{array}$ \\
\hline 49 & $\mathrm{HEl}$ & HEG & $Y$ & $8(8)$ & EDW & EDW (0) & $\mathrm{EDW}^{*}$ & EDW* & $\mathrm{EDW}^{*}$ & $\mathrm{EDW}^{*}$ \\
\hline 50 & NAD & NAW & $Y$ & $15(15)$ & EDW & EDW (0) & $\mathrm{EDW}^{*}$ & EDW* & $\mathrm{EDW}^{*}$ & $\mathrm{EDW}^{*}$ \\
\hline 51 & OMO & $\mathrm{OPH}$ & $Y$ & 11(11) & EDW & EDW (0) & $\mathrm{EDW}^{*}$ & EDW* & $\mathrm{EDW}^{*}$ & $\mathrm{EDW}^{*}$ \\
\hline 52 & SER & SOR & $Y$ & $10(9)$ & EDW & EDW (0) & $\mathrm{EDW}^{*}$ & EDW* & $\mathrm{EDW}^{*}$ & $\mathrm{EDW}^{*}$ \\
\hline 53 & FUM & FAC & $\mathrm{Y}$ & $5(4)$ & ELF & $\operatorname{ELF}(0)$ & $E^{\prime} F^{*}$ & $E^{\prime} F^{*}$ & $E^{\prime} F^{*}$ & $E^{\prime} F^{*}$ \\
\hline 54 & FUM & FUZ & $Y$ & $2(2)$ & ELF & ELF (0) & $\mathrm{ELF}^{*}$ & $E L F^{*}$ & $\mathrm{ELF}^{*}$ & $\mathrm{ELF}^{*}$ \\
\hline 55 & $\mathrm{HAL}$ & $\mathrm{HOL}$ & $Y$ & $5(3)$ & ELF & ELF (0) & $E^{\prime} F^{*}$ & ELF* & ELF* & $E^{\prime} F^{*}$ \\
\hline 56 & HEK & HIB & $Y$ & $6(4)$ & ELF & ELF (0) & $E L F^{*}$ & $\mathrm{ELF}^{*}$ & $E L F^{*}$ & $E L F^{*}$ \\
\hline 57 & NAD & NUT & $Y$ & $10(10)$ & ELF & ELF (0) & $\mathrm{ELF}^{*}$ & $\mathrm{ELF}^{*}$ & $\mathrm{ELF}^{*}$ & $\mathrm{ELF}^{*}$ \\
\hline 58 & NYA & NAT & $Y$ & $4(4)$ & ELF & ELF (0) & $\mathrm{ELF}^{*}$ & ELF* & ELF* & $E L F^{*}$ \\
\hline 59 & SER & SAU & $Y$ & $5(3)$ & ELF & ELF (0) & $\mathrm{ELF}^{*}$ & ELF* & $E^{\prime} F^{*}$ & $E^{\prime} F^{*}$ \\
\hline 60 & SID & SHA & $\mathrm{N}$ & $5(5)$ & ELF & ELF (0) & $\mathrm{ELF}^{*}$ & $\mathrm{ELF}^{*}$ & $E^{\prime} F^{*}$ & $\mathrm{ELF}^{*}$ \\
\hline 61 & HAM & MON & $Y$ & $12(12)$ & EXO & EXO (0) & $\mathrm{EXO}^{*}$ & EXO* & EXO* & EXO* \\
\hline 62 & $\mathrm{HOL}$ & BIM & $Y$ & $11(11)$ & EXO & EXO (0) & EXO* & $\mathrm{EXO}^{*}$ & EXO* & EXO* \\
\hline 63 & WHI & WAG & $\mathrm{Y}$ & $15(14)$ & FAT & FAT (0) & FAT $^{*}$ & $\mathrm{FAT}^{*}$ & $\mathrm{FAT}^{*}$ & $\mathrm{FAT}^{*}$ \\
\hline 64 & LAM & LOF & $N$ & $16(16)$ & FAV & FAV (0) & $\mathrm{FAV}^{*}$ & $\mathrm{FAV}^{*}$ & $\mathrm{FAV}^{*}$ & $\mathrm{FAV}^{*}$ \\
\hline 65 & LIM & $\mathrm{LAX}$ & $\mathrm{Y}$ & $8(8)$ & FAV & FAV (0) & $\mathrm{FAV}^{*}$ & $\mathrm{FAV}^{*}$ & $\mathrm{FAV}^{*}$ & $\mathrm{FAV}^{*}$ \\
\hline 66 & NIX & $\mathrm{NCH}$ & $Y$ & $16(16)$ & FAV & FAV (0) & $\mathrm{FAV}^{*}$ & $\mathrm{FAV}^{*}$ & $\mathrm{FAV}^{*}$ & $\mathrm{FAV}^{*}$ \\
\hline 67 & WAG & WOB & $Y$ & $8(8)$ & FAV & FAV (0) & $\mathrm{FAV}^{*}$ & $\mathrm{FAV}^{*}$ & $\mathrm{FAV}^{*}$ & $\mathrm{FAV}^{*}$ \\
\hline 68 & LAR & LOQ & $Y$ & $6(6)$ & FEL & FEL (0) & $\mathrm{FEL}^{*}$ & $\mathrm{FEL}^{*}$ & $\mathrm{FEL}^{*}$ & $\mathrm{FEL}^{*}$ \\
\hline 69 & MYS & MBE & $Y$ & $10(10)$ & FEL & FEL (0) & $\mathrm{FEL}^{*}$ & $\mathrm{FEL}^{*}$ & $\mathrm{FEL}^{*}$ & $\mathrm{FEL}^{*}$ \\
\hline 70 & NIG & NYE & $Y$ & 7(7) & FEL & FEL (0) & $\mathrm{FEL}^{*}$ & $\mathrm{FEL}^{*}$ & $\mathrm{FEL}^{*}$ & $\mathrm{FEL}^{*}$ \\
\hline 71 & NIX & NET & $Y$ & $6(6)$ & FEL & FEL (0) & $\mathrm{FEL}^{*}$ & $\mathrm{FEL}^{*}$ & $\mathrm{FEL}^{*}$ & $\mathrm{FEL}^{*}$ \\
\hline 72 & WEM & WIP & $\mathrm{Y}$ & $5(5)$ & FEL & FEL (0) & $\mathrm{FEL}^{*}$ & $\mathrm{FEL}^{*}$ & $\mathrm{FEL}^{*}$ & $\mathrm{FEL}^{*}$ \\
\hline 73 & $\mathrm{CHE}$ & CRU & $Y$ & $15(14)$ & GAS & GAS (0) & GAS* & GAS* & GAS* & GAS* \\
\hline 74 & FAC & FAX & $Y$ & 11(11) & GAS & GAS (0) & GAS* & GAS* & GAS* & GAS* \\
\hline 75 & HEK & $\mathrm{HAZ}$ & $Y$ & $13(13)$ & GAS & GAS (0) & GAS* & GAS* & GAS* & GAS* \\
\hline 76 & SER & SNA & $Y$ & $14(13)$ & GAS & GAS (0) & GAS* & GAS* & GAS* & GAS* \\
\hline 77 & DOT & DOV & $Y$ & $15(13)$ & GIZ & GIZ (0) & $\mathrm{GIZ}^{*}$ & $\mathrm{GIZ}^{*}$ & GIZ* & GIZ* \\
\hline 78 & ORE & ORY & $\mathrm{N}$ & $15(15)$ & GIZ & GIZ (0) & GIZ* & GIZ* & $\mathrm{GIZ} \dagger$ & $\mathrm{GIZ}^{*}$ \\
\hline 79 & VIX & VIN & $Y$ & $15(14)$ & GIZ & GIZ (0) & $\mathrm{GIZ}^{*}$ & GIZ* & $\mathrm{GIZ}^{*}$ & $\mathrm{GIZ}^{*}$ \\
\hline 80 & SAN & SER & $\mathrm{N}$ & $13(11)$ & GOL & GOL (0) & $\mathrm{GOL}^{*}$ & $\mathrm{GOL}^{*}$ & $\mathrm{GOL}^{*}$ & $\mathrm{GOL}^{*}$ \\
\hline 81 & LON & LAI & $\mathrm{N}$ & $16(16)$ & HNS & HNS (0) & HNS* & HNS* & $\mathrm{HNS} \dagger$ & HNS* \\
\hline 82 & LAD & LAN & $\mathrm{Y}$ & $8(8)$ & IAG & IAG (0) & $\mathrm{IAG}^{\star}$ & $\mathrm{IAG}^{\star}$ & $I A G^{*}$ & $\mathrm{IAG}^{*}$ \\
\hline 83 & NOB & NOO & $Y$ & $9(9)$ & IAG & IAG (0) & $\mathrm{IAG}^{*}$ & $\mathrm{IAG}^{*}$ & $\mathrm{IAG}^{*}$ & $\mathrm{IAG}^{\star}$ \\
\hline 84 & DRO & DAK & $Y$ & $15(14)$ & ICA & ICA (0) & $\mathrm{ICA}^{*}$ & $\mathrm{ICA}^{*}$ & $\mathrm{ICA}^{*}$ & $\mathrm{ICA}^{*}$ \\
\hline 85 & WAD & WRA & $\mathrm{Y}$ & $12(12)$ & ICA & ICA (0) & $\mathrm{ICA}^{*}$ & $\mathrm{ICA}^{*}$ & $\mathrm{ICA}^{*}$ & $\mathrm{ICA}^{*}$ \\
\hline 86 & ALF & ASH & $\mathrm{N}$ & $15(13)$ & INZ & INZ (0) & INZ* & INZ* & INZ* & INZ* \\
\hline 87 & DOT & DIV & $Y$ & $5(5)$ & INZ & INZ (0) & INZ* & INZ* & INZ* & INZ* \\
\hline 88 & ELL & $\mathrm{ECH}$ & $\mathrm{N}$ & $15(13)$ & INZ & INZ (0) & $\mathrm{INZ}^{*}$ & $\mathrm{INZ}^{*}$ & $\mathrm{INZ}^{*}$ & $\mathrm{INZ}^{*}$ \\
\hline 89 & HAN & HAM & $Y$ & $13(12)$ & INZ & INZ (0) & INZ* & $\mathrm{INZ}^{*}$ & $\mathrm{INZ}^{*}$ & INZ* \\
\hline 90 & OMO & OFR & $\mathrm{Y}$ & $15(12)$ & INZ & INZ (0) & $\mathrm{INZ}^{*}$ & $\mathrm{INZ}^{*}$ & $\mathrm{INZ}^{*}$ & $\mathrm{INZ}^{*}$ \\
\hline 91 & ORE & OST & $\mathrm{N}$ & $15(13)$ & INZ & INZ (0) & INZ* & INZ* & $\mathrm{INZ}^{*}$ & $\mathrm{INZ} \dagger$ \\
\hline 92 & VIV & VIL & $\mathrm{Y}$ & $4(3)$ & INZ & INZ (0) & INZ* & $\mathrm{INZ}^{*}$ & INZ* & $\mathrm{INZ}^{*}$ \\
\hline 93 & VIX & VET & $\mathrm{Y}$ & $4(3)$ & INZ & INZ (0) & INZ* & INZ* & INZ* & INZ* \\
\hline 94 & VOR & VAN & $\mathrm{Y}$ & $5(5)$ & INZ & INZ (0) & $\mathrm{INZ}{ }^{*}$ & INZ* & INZ* & INZ* \\
\hline 95 & LAR & LAT & $Y$ & 4(4) & JIT & JIT (0) & JIT* & JIT* & $J T^{*}$ & $J T^{*}$ \\
\hline 96 & LIN & LUG & $Y$ & 11(11) & נIT & IIT (0) & JIT* & $\mathrm{JIT}^{*}$ & $\mathrm{JIT}^{*}$ & JIT* \\
\hline 97 & NEE & NAV & $\mathrm{Y}$ & $10(10)$ & נIT & IIT (0) & JIT* & JIT* & $\mathrm{JIT}^{*}$ & JIT* \\
\hline 98 & NIX & $\mathrm{NAI}$ & $Y$ & $6(6)$ & נIT & IIT (0) & JIT* & JIT* & JIT* & JIT* \\
\hline 99 & WEA & WAT & $Y$ & $9(9)$ & JIT & IIT (0) & JIT* & JIT* & JIT* & JIT* \\
\hline 100 & WEM & WEU & $\mathrm{Y}$ & $7(7)$ & JIT & IIT (0) & JIT* & JIT* & JIT* & JIT* \\
\hline 101 & KEL & KOL & $Y$ & $14(13)$ & KEI & KEI (0) & $\mathrm{KEI}^{*}$ & $\mathrm{KEI}^{*}$ & $\mathrm{KEI}^{*}$ & $\mathrm{KEI}^{*}$ \\
\hline 102 & LAR & LAD & $\mathrm{Y}$ & $10(10)$ & KEI & KEI (0) & $\mathrm{KEI}^{*}$ & $\mathrm{KEI}^{*}$ & $\mathrm{KEI}^{*}$ & $\mathrm{KEI}^{*}$ \\
\hline 103 & NIX & NAP & $Y$ & 11(11) & KEI & KEI (0) & $\mathrm{KEI}^{*}$ & $\mathrm{KEI}^{*}$ & $\mathrm{KEI}^{*}$ & $\mathrm{KEI}^{*}$ \\
\hline 104 & NYO & NYU & $Y$ & $14(14)$ & KEI & KEI (0) & $\mathrm{KEI}^{*}$ & $\mathrm{KEI}^{*}$ & $\mathrm{KEI}^{*}$ & $\mathrm{KEI}^{*}$ \\
\hline 105 & WEM & WAD & $Y$ & $9(9)$ & KEI & KEI (0) & $\mathrm{KEI}^{*}$ & $\mathrm{KEI}^{*}$ & $\mathrm{KEl}^{*}$ & $\mathrm{KEI}^{*}$ \\
\hline 106 & WEM & WAS & $Y$ & $16(16)$ & KEI & $\mathrm{KEI}(0)$ & $\mathrm{KEI}^{*}$ & $\mathrm{KEI}^{*}$ & $\mathrm{KEI}^{*}$ & $\mathrm{KEI}^{*}$ \\
\hline 107 & VOT & $\mathrm{RHO}$ & $Y$ & $12(12)$ & KER & KER (0) & $\mathrm{KER}^{*}$ & KER* & $\mathrm{KER}^{*}$ & $\mathrm{KER}^{*}$ \\
\hline 108 & NAP & NOZ & $Y$ & 11(11) & KIL & KIL (0) & $\mathrm{KIL}^{*}$ & $\mathrm{KIL}^{*}$ & $\mathrm{KIL}^{*}$ & $\mathrm{KIL}^{*}$ \\
\hline 109 & VOR & RAN & $\mathrm{Y}$ & $9(9)$ & LIB & LIB (1) & LIB* & LIB* & MLO $\dagger$ & LIB* \\
\hline 110 & LAR & LEX & $Y$ & $4(4)$ & $\mathrm{LIO} \S$ & LIO (0) & $\mathrm{LIO}^{*}$ & $\mathrm{LIO}^{*}$ & LIO* & $\mathrm{LIO}^{*}$ \\
\hline 111 & VIO & EPS & $\mathrm{Y}$ & $9(9)$ & $\mathrm{LIO}$ & LIO (0) & $\mathrm{LIO}^{*}$ & $\mathrm{LIO}^{*}$ & $\mathrm{LIO}^{*}$ & $\mathrm{LIO}^{*}$ \\
\hline 112 & VAA & YAI & $\mathrm{Y}$ & $9(9)$ & LOF & LOF (0) & LOF* $^{*}$ & LOF* $^{*}$ & LOF* $^{*}$ & LOF* $^{*}$ \\
\hline 113 & VEL & EVA & $Y$ & $9(9)$ & LOF & LOF (0) & LOF* $^{*}$ & LOF* $^{*}$ & LOF* $^{*}$ & LOF* $^{*}$ \\
\hline
\end{tabular}


Table A1 (continued)

\begin{tabular}{|c|c|c|c|c|c|c|c|c|c|c|}
\hline \multirow[b]{2}{*}{ Count } & \multirow[b]{2}{*}{ Mother } & \multirow[b]{2}{*}{ Offspring } & \multirow[b]{2}{*}{$\begin{array}{c}\text { Mother } \\
\text { sampled? }\end{array}$} & \multirow{2}{*}{$\begin{array}{c}\text { Number of } \\
\text { potential fathers } \\
\text { (number genotyped) }\end{array}$} & \multirow[b]{2}{*}{$\begin{array}{l}\text { Concensus } \\
\text { father }\end{array}$} & \multirow{2}{*}{$\begin{array}{l}\text { Male excluded } \\
\text { at fewest loci } \\
\text { (number of loci } \\
\text { excluded at) }\end{array}$} & \multicolumn{4}{|c|}{ \% Error } \\
\hline & & & & & & & 1 & 5 & 10 & $\begin{array}{l}\text { All males in } \\
\text { population } \ddagger\end{array}$ \\
\hline 114 & VIN & YOG & $\mathrm{Y}$ & $12(12)$ & MLO & MLO (0) & MLO* & MLO* & MLO* & MLO* \\
\hline 115 & VIX & VIB & $\mathrm{Y}$ & $12(12)$ & MLO & MLO (0) & MLO* & MLO* & MLO* & MLO* \\
\hline 116 & VOR & VAT & $\mathrm{Y}$ & $10(9)$ & MLO & MLO (0) & MLO* & MLO* & MLO* & MLO* \\
\hline 117 & LEL & LAS & $\mathrm{Y}$ & $14(14)$ & NEL & NEL (0) & NEL* & NEL* & NEL* & NEL* \\
\hline 118 & $\mathrm{CHE}$ & $\mathrm{CHR}$ & $\mathrm{Y}$ & 15(13) & NEP & NEP (0) & NEP* & NEP* & NEP* & NEP* \\
\hline 119 & DUD & DRO & $\mathrm{Y}$ & $15(13)$ & NEP & NEP (0) & NEP* & NEP* & NEP* & NEP* \\
\hline 120 & FUM & FED & $\mathrm{Y}$ & $15(13)$ & NEP & $\operatorname{NEP}(0)$ & NEP* & NEP* & NEP* & NEP* \\
\hline 121 & $\mathrm{HEI}$ & HYR & $\mathrm{Y}$ & $15(13)$ & NEP & NEP (0) & NEP* & NEP* & NEP* & NEP* \\
\hline 122 & SAN & SOU & $\mathrm{N}$ & $4(4)$ & NEP & NEP (0) & NEP* & NEP* & NEP* & NEP* \\
\hline 123 & VIX & VIP & $\mathrm{Y}$ & $16(13)$ & NGG & NGG (0) & $\mathrm{NGG}^{*}$ & $\mathrm{NGG}^{*}$ & $\mathrm{NGG}^{*}$ & $\mathrm{NGG}^{*}$ \\
\hline 124 & HEK & HOK & $\mathrm{Y}$ & $10(10)$ & NOA & NOA (0) & $\mathrm{NOA}^{*}$ & $\mathrm{NOA}^{*}$ & $\mathrm{NOA}^{*}$ & $\mathrm{NOA}^{*}$ \\
\hline 125 & $\mathrm{HEI}$ & HAP & $\mathrm{Y}$ & $5(4)$ & NOL & NOL (0) & $\mathrm{NOL}^{*}$ & $\mathrm{NOL}^{*}$ & $\mathrm{NOL}^{*}$ & $\mathrm{NOL}^{*}$ \\
\hline 126 & HEI & HEL & $\mathrm{Y}$ & $15(13)$ & $\mathrm{NOL}$ & NOL (1) & $\mathrm{NOL}^{*}$ & $\mathrm{NOL}^{*}$ & $\mathrm{NOL}^{*}$ & $\mathrm{NOL}^{*}$ \\
\hline 127 & SOU & SEW & $\mathrm{Y}$ & 13(13) & NYU & NYU (0) & NYU* & NYU* & NYU* & NYU* \\
\hline 128 & VEL & VIA & $\mathrm{Y}$ & $12(12)$ & ORB & ORB (0) & ORB* & ORB* & $\mathrm{ORB}^{*}$ & ORB* \\
\hline 129 & VIV & VEX & $\mathrm{Y}$ & $12(12)$ & ORB & ORB (0) & ORB* & ORB* & ORB* & ORB* \\
\hline 130 & LAS & LEI & $\mathrm{Y}$ & $12(12)$ & ORY & ORY (0) & ORY* & ORY* & ORY* & ORY* \\
\hline 131 & LID & LUP & $\mathrm{Y}$ & $11(11)$ & ORY & ORY (0) & ORY* & ORY* & ORY* & ORY* \\
\hline 132 & KEL & KER & $\mathrm{Y}$ & $17(17)$ & PEP & $\operatorname{PEP}(0)$ & PEP* & PEP* & PEP* & PEP* \\
\hline 133 & LIM & LAZ & $Y$ & $15(15)$ & PEP & PEP (0) & PEP* & PEP* & PEP* & PEP* \\
\hline 134 & MOJ & MYS & $\mathrm{N}$ & $16(16)$ & PEP & PEP (0) & PEP* & PEP* & PEP† & PEP* \\
\hline 135 & NIG & NOB & $\mathrm{Y}$ & $11(11)$ & PEP & $\operatorname{PEP}(0)$ & PEP* & PEP* & PEP* & PEP* \\
\hline 136 & WAK & WOM & $Y$ & 16(16) & PEP & PEP (0) & PEP* & PEP* & PEP* & PEP* \\
\hline 137 & DOV & DAG & $Y$ & $12(12)$ & PIS & PIS (0) & $\mathrm{PIS}^{*}$ & PIS* & PIS* & PIS* \\
\hline 138 & DOV & DOX & $\mathrm{Y}$ & $12(12)$ & PIS & PIS (0) & PIS* $^{*}$ & PIS* $^{*}$ & PIS* & $\mathrm{PIS}^{*}$ \\
\hline 139 & DOV & DUB & $\mathrm{Y}$ & $7(7)$ & PIS & PIS (0) & PIS* & PIS* & PIS* & PIS* \\
\hline 140 & $\mathrm{ECH}$ & ELV & $\mathrm{Y}$ & $8(8)$ & PIS & PIS (0) & PIS* & PIS* & PIS* & PIS* $^{*}$ \\
\hline 141 & VIN & VOC & $\mathrm{Y}$ & $12(12)$ & PIS & PIS (0) & PIS* & PIS* & PIS* & PIS* \\
\hline 142 & VIX & VOY & $Y$ & $10(9)$ & PIS & PIS (0) & PIS* & PIS* & PIS* & PIS* \\
\hline 143 & $\mathrm{CHE}$ & $C A B$ & Y & $10(10)$ & PLA & PLA (0) & PLA $^{*}$ & PLA $^{*}$ & PLA $^{*}$ & PLA $^{*}$ \\
\hline 144 & DRO & DEC & $Y$ & $13(13)$ & PLA & PLA (0) & $\mathrm{PLA}^{*}$ & PLA* $^{*}$ & PLA $^{*}$ & $\mathrm{PLA}^{*}$ \\
\hline 145 & HAL & HYM & $\mathrm{Y}$ & $15(15)$ & PLA & PLA (0) & PLA $^{*}$ & PLA $^{*}$ & PLA $^{*}$ & $\mathrm{PLA}^{*}$ \\
\hline 146 & LAR & LAW & $\mathrm{Y}$ & $9(9)$ & PLA & PLA (0) & $\mathrm{PLA}^{*}$ & $\mathrm{PLA}^{*}$ & $\mathrm{PLA}^{*}$ & $\mathrm{PLA}^{*}$ \\
\hline 147 & LEL & LIB & $\mathrm{Y}$ & $17(17)$ & POL & POL (0) & $\mathrm{POL}^{*}$ & $\mathrm{POL}^{*}$ & $\mathrm{POL}^{*}$ & $\mathrm{POL}^{*}$ \\
\hline 148 & LIM & LID & $\mathrm{Y}$ & 14(14) & POL & POL (0) & $\mathrm{POL}^{*}$ & $\mathrm{POL}^{*}$ & $\mathrm{POL}^{*}$ & $\mathrm{POL}^{*}$ \\
\hline 149 & NIP & NAF & $\mathrm{Y}$ & $16(16)$ & POL & POL (0) & $\mathrm{POL}^{*}$ & $\mathrm{POL}^{*}$ & $\mathrm{POL}^{*}$ & $\mathrm{POL}^{*}$ \\
\hline 150 & PRU & POU & $\mathrm{Y}$ & $15(15)$ & POL & POL (0) & $\mathrm{POL}^{*}$ & $\mathrm{POL}^{*}$ & $\mathrm{POL}^{*}$ & $\mathrm{POL}^{*}$ \\
\hline 151 & WEN & WID & $\mathrm{Y}$ & $14(14)$ & POL & POL (0) & $\mathrm{POL}^{*}$ & $\mathrm{POL}^{*}$ & $\mathrm{POL}^{*}$ & $\mathrm{POL}^{*}$ \\
\hline 152 & ASH & ADO & $\mathrm{Y}$ & $2(2)$ & POW & POW (0) & $\mathrm{POW}^{*}$ & $\mathrm{POW}^{*}$ & $\mathrm{POW}^{*}$ & POW* $^{*}$ \\
\hline 153 & DUI & DAS & $\mathrm{Y}$ & $2(2)$ & POW & POW (0) & $\mathrm{POW}^{*}$ & $\mathrm{POW}^{*}$ & POW* & POW* \\
\hline 154 & $\mathrm{ECH}$ & ELB & $Y$ & 11(11) & POW & POW (0) & $\mathrm{POW}^{*}$ & $\mathrm{POW}^{*}$ & $\mathrm{POW}^{*}$ & POW* $^{*}$ \\
\hline 155 & OFR & $\mathrm{OOZ}$ & $\mathrm{Y}$ & $2(2)$ & POW & POW (0) & $\mathrm{POW}^{*}$ & $\mathrm{POW}^{*}$ & POW* & POW* \\
\hline 156 & OFR & OXY & $\mathrm{Y}$ & $12(12)$ & POW & POW (0) & $\mathrm{POW}^{*}$ & $\mathrm{POW}^{*}$ & POW* & POW* \\
\hline 157 & OMO & OZO & $\mathrm{Y}$ & $2(2)$ & POW & POW (0) & POW* $^{*}$ & $\mathrm{POW}^{*}$ & POW* & POW* \\
\hline 158 & OST & ONY & $Y$ & $3(3)$ & POW & POW (0) & $\mathrm{POW}^{*}$ & POW* $^{*}$ & POW* $^{*}$ & POW* $^{*}$ \\
\hline 159 & OST & ORI & $\mathrm{Y}$ & $12(12)$ & POW & POW (0) & $\mathrm{POW}^{*}$ & $\mathrm{POW}^{*}$ & $\mathrm{POW}^{*}$ & POW* $^{*}$ \\
\hline 160 & KEL & KEP & $\mathrm{Y}$ & $3(3)$ & ROC & $\mathrm{ROC}(0)$ & $\mathrm{ROC}^{*}$ & $\mathrm{ROC}^{*}$ & $\mathrm{ROC}^{*}$ & $\mathrm{ROC}^{*}$ \\
\hline 161 & LAZ & LOX & $\mathrm{Y}$ & $14(14)$ & ROC & ROC (0) & $\mathrm{ROC}^{*}$ & $\mathrm{ROC}^{*}$ & $\mathrm{ROC} \dagger$ & $\mathrm{ROC}^{*}$ \\
\hline 162 & LIM & LIZ & $\mathrm{Y}$ & $3(3)$ & ROC & ROC (0) & $\mathrm{ROC}^{*}$ & $\mathrm{ROC}^{*}$ & $\mathrm{ROC}^{*}$ & $\mathrm{ROC}^{*}$ \\
\hline 163 & LUN & LEG & $\mathrm{Y}$ & $14(13)$ & ROC & $\mathrm{ROC}(0)$ & $\mathrm{ROC}^{*}$ & $\mathrm{ROC}^{*}$ & $\mathrm{ROC}^{*}$ & $\mathrm{ROC}^{*}$ \\
\hline 164 & PRU & PEB & $\mathrm{Y}$ & $10(10)$ & ROC & ROC (0) & $\mathrm{ROC}^{*}$ & $\mathrm{ROC}^{*}$ & $\mathrm{ROC}^{*}$ & $\mathrm{ROC}^{*}$ \\
\hline 165 & PRU & POK & $\mathrm{Y}$ & $5(5)$ & ROC & ROC (0) & $\mathrm{ROC}^{*}$ & $\mathrm{ROC}^{*}$ & $\mathrm{ROC}^{*}$ & $\mathrm{ROC}^{*}$ \\
\hline 166 & PRU & POT & $Y$ & $9(9)$ & ROC & ROC (0) & $\mathrm{ROC}^{*}$ & $\mathrm{ROC}^{*}$ & $\mathrm{ROC}^{*}$ & $\mathrm{ROC}^{*}$ \\
\hline 167 & WAG & WES & $\mathrm{Y}$ & $2(2)$ & ROC & ROC (0) & $\mathrm{ROC}^{*}$ & $\mathrm{ROC}^{*}$ & $\mathrm{ROC}^{*}$ & $\mathrm{ROC}^{*}$ \\
\hline 168 & WAG & WHO & $\mathrm{Y}$ & $14(14)$ & ROC & $\mathrm{ROC}(0)$ & $\mathrm{ROC}^{*}$ & $\mathrm{ROC}^{*}$ & $\mathrm{ROC}^{*}$ & $\mathrm{ROC}^{*}$ \\
\hline 169 & WEA & WHE & $\mathrm{Y}$ & $4(4)$ & ROC & ROC (0) & $\mathrm{ROC}^{*}$ & $\mathrm{ROC}^{*}$ & $\mathrm{ROC}^{*}$ & $\mathrm{ROC}^{*}$ \\
\hline 170 & WEN & WEX & $\mathrm{Y}$ & $15(15)$ & $\mathrm{ROC}$ & $\mathrm{ROC}(0)$ & $\mathrm{ROC}^{*}$ & $\mathrm{ROC}^{*}$ & $\mathrm{ROC}^{*}$ & $\mathrm{ROC}^{*}$ \\
\hline 171 & WEN & WIG & $\mathrm{Y}$ & $2(2)$ & ROC & ROC (0) & $\mathrm{ROC}^{*}$ & $\mathrm{ROC}^{*}$ & $\mathrm{ROC}^{*}$ & $\mathrm{ROC}^{*}$ \\
\hline 172 & WEN & WIR & $\mathrm{Y}$ & $11(10)$ & ROC & $\mathrm{ROC}(0)$ & $\mathrm{ROC}^{*}$ & $\mathrm{ROC}^{*}$ & $\mathrm{ROC}^{*}$ & $\mathrm{ROC}^{*}$ \\
\hline 173 & WEN & WIS & $\mathrm{Y}$ & $14(13)$ & ROC & $\mathrm{ROC}(0)$ & $\mathrm{ROC}^{*}$ & $\mathrm{ROC}^{*}$ & $\mathrm{ROC}^{*}$ & $\mathrm{ROC}^{*}$ \\
\hline 174 & LAS & LUI & $\mathrm{Y}$ & $3(3)$ & ROC & ROC (1) & $\mathrm{ROC}^{*}$ & $\mathrm{ROC}^{*}$ & $\mathrm{ROC}^{*}$ & $\mathrm{ROC}^{*}$ \\
\hline 175 & PRU & PAI & $Y$ & 13(13) & $\mathrm{ROC}$ & $\mathrm{ROC}(0)$ & $\mathrm{ROC}^{*}$ & $\mathrm{ROC}^{*}$ & $\mathrm{ROC}^{*}$ & $\mathrm{ROC}^{*}$ \\
\hline 176 & OST & OAT & $\mathrm{Y}$ & $8(8)$ & ROY & ROY (0) & ROY* & ROY* & ROY* & ROY* $^{*}$ \\
\hline 177 & VOR & VAI & $\mathrm{Y}$ & $11(11)$ & ROY & ROY (0) & $\mathrm{ROY}^{*}$ & $\mathrm{ROY}^{*}$ & ROY* & ROY* \\
\hline
\end{tabular}


Table A1 (continued)

\begin{tabular}{|c|c|c|c|c|c|c|c|c|c|c|}
\hline \multirow[b]{2}{*}{ Count } & \multirow[b]{2}{*}{ Mother } & \multirow[b]{2}{*}{ Offspring } & \multirow[b]{2}{*}{$\begin{array}{l}\text { Mother } \\
\text { sampled? }\end{array}$} & \multirow{2}{*}{$\begin{array}{c}\text { Number of } \\
\text { potential fathers } \\
\text { (number genotyped) }\end{array}$} & \multirow[b]{2}{*}{$\begin{array}{c}\text { Concensus } \\
\text { father }\end{array}$} & \multirow{2}{*}{$\begin{array}{l}\text { Male excluded } \\
\text { at fewest loci } \\
\text { (number of loci } \\
\text { excluded at) }\end{array}$} & \multicolumn{4}{|c|}{$\%$ Error } \\
\hline & & & & & & & 1 & 5 & 10 & $\begin{array}{l}\text { All males in } \\
\text { population }\end{array}$ \\
\hline 178 & KAT & KUK & $\mathrm{N}$ & $14(13)$ & RUT & RUT (0) & RUT* & $\mathrm{KUZ}+$ & KUZ† & RUT† \\
\hline 179 & LON & LAV & $\mathrm{N}$ & $17(17)$ & RUT & RUT (0) & RUT* & RUT** & RUT** & RUT* \\
\hline 180 & HEK & HIM & $\mathrm{Y}$ & $10(10)$ & SAW $\S$ & SAW $(0)$ & SAW* & SAW* & SAW* & $\mathrm{SAW}^{*}$ \\
\hline 181 & VEN & VAC & $\mathrm{N}$ & $3(2)$ & SUD $\S^{* * *}$ & MLI (8), INZ (8) & MLI & INZ & INZ $†$ & UNG \\
\hline 182 & DUD & DAT & $\mathrm{Y}$ & $15(14)$ & SUJ & sÜ (0) & SUJ* & SUJ* & $\mathrm{GAS}^{*}$ & SUJ* \\
\hline 183 & DOT & DUI & $\mathrm{Y}$ & $2(2)$ & TUZ & TUZ (0) & TUZ* & TUZ* & TUZ* & TUZ* \\
\hline 184 & DOV & DEA & $Y$ & $2(2)$ & TUZ & TUZ (0) & TUZ* & TUZ* & TUZ* & TUZ* \\
\hline 185 & DOV & DUN & $Y$ & $3(3)$ & TUZ & TUZ (0) & TUZ* & TUZ* & TUZ* & TUZ $^{*}$ \\
\hline 186 & $\mathrm{OCH}$ & $\mathrm{OBI}$ & $Y$ & $3(3)$ & TUZ & TUZ (0) & TUZ* & TUZ* & TUZ* & TUZ* \\
\hline 187 & OMO & OKO & $\mathrm{Y}$ & $2(2)$ & TUZ & TUZ (0) & TUZ* & TUZ* & TUZ* & TUZ* \\
\hline 188 & VEL & VEI & $Y$ & $3(3)$ & TUZ & TUZ (0) & TUZ* & TUZ* & $\mathrm{TUZ}^{*}$ & TUZ* \\
\hline 189 & VEL & $\mathrm{VIO}$ & $Y$ & $4(4)$ & TUZ & TUZ (0) & TUZ* & TUZ* & TUZ* & TUZ* \\
\hline 190 & VIN & VAA & $Y$ & $2(2)$ & TUZ & TUZ (0) & TUZ* & TUZ* & TUZ* & TUZ* \\
\hline 191 & VIN & VAP & Y & $8(8)$ & TUZ & TUZ (0) & TUZ* & TUZ* & TUZ* & TUZ* \\
\hline 192 & VIV & VAZ & $Y$ & $2(2)$ & TUZ & TUZ (0) & TUZ* & TUZ* & TUZ* & TUZ* \\
\hline 193 & VOR & VOT & $Y$ & $2(2)$ & TUZ & TUZ (0) & TUZ* & TUZ* & TUZ* $^{*}$ & TUZ* \\
\hline 194 & HAN & $\mathrm{HAL}$ & $Y$ & $13(11)$ & TYC & TYC (0) & TYC* & TYC* & TYC* & TYC* \\
\hline 195 & NYA & NAD & $\mathrm{Y}$ & $15(13)$ & TYC & TYC (0) & TYC* & TYC* & TYC* & TYC* \\
\hline 196 & OMO & $\mathrm{OCH}$ & $Y$ & $15(14)$ & TYC & TYC (0) & TYC* & TYC* & TYC* & TYC* \\
\hline 197 & VIV & VID & $\mathrm{Y}$ & $15(13)$ & TYC & TYC (0) & TYC* & TYC* & TYC* & TYC* \\
\hline 198 & $\mathrm{KOL}$ & KUT & $Y$ & $14(14)$ & VAN & VAN (0) & VAN* & VAN* & $\mathrm{VAN}^{*}$ & VAN* \\
\hline 199 & LID & LUM & $Y$ & $14(14)$ & VAN & VAN (0) & VAN* ${ }^{*}$ & VAN* & VAN* & VAN* \\
\hline 200 & LOC & CAD & $\mathrm{Y}$ & $15(15)$ & VAN & VAN (0) & VAN* $^{*}$ & VAN* & $\mathrm{VAN}^{*}$ & VAN* \\
\hline 201 & WHE & WRE & $Y$ & 11(11) & VAN & VAN (0) & VAN* & VAN* & VAN* & VAN* ${ }^{*}$ \\
\hline 202 & $\mathrm{OMO}$ & OCE & $\mathrm{Y}$ & $9(9)$ & VEG & VEG (0) & VEG* & VEG* & VEG* & VEG* \\
\hline 203 & VET & THR & $Y$ & 11(11) & VEG & VEG (1) & VEG* & VEG* & VEG* & VEG* \\
\hline 204 & VIV & VOG & $\mathrm{Y}$ & $10(9)$ & VEG & VEG (0) & VEG* & VEG* & VEG* & VEG* \\
\hline 205 & NYA & NES & $Y$ & $15(14)$ & YOY & YOY (0) & YOY* & YOY* & YOY* & YOY* \\
\hline 206 & MYS & MEX & $Y$ & $11(11)$ & ZAl & $\mathrm{ZAI}(0)$ & $\mathrm{ZAI}^{*}$ & $\mathrm{ZAl}^{*}$ & $\mathrm{ZAl}^{*}$ & $\mathrm{ZAI}^{*}$ \\
\hline 207 & WAS & WOO & $\mathrm{Y}$ & 11(11) & ZIN & ZIN (0) & $\mathrm{ZIN}^{*}$ & $\mathrm{ZIN}^{*}$ & $\mathrm{ZIN}^{*}$ & $\mathrm{NYU}+$ \\
\hline 208 & WEM & WYL & $Y$ & 11(11) & ZIN & ZIN (0) & $\mathrm{ZIN}^{*}$ & $\mathrm{ZIN}^{*}$ & $\mathrm{ZIN}^{*}$ & $\mathrm{ZIN}^{*}$ \\
\hline 209 & DUD & DEL & $Y$ & $15(13)$ & $? \dagger \dagger$ & & & & & \\
\hline 210 & LIM & LAL & $Y$ & $15(15)$ & $?+\dagger$ & & & & & \\
\hline 211 & PEN & PES & $\mathrm{N}$ & $14(13)$ & $?+\ddagger$ & MSW (1) & $\mathrm{MSW}^{*}$ & MSW* & $M S W \dagger$ & $M S W \dagger$ \\
\hline 212 & SPE & SIT & $\mathrm{N}$ & $14(12)$ & $? \S \S$ & NOL/POL (0) & $\mathrm{NOL}^{*}$ & $\mathrm{NOL}^{*}$ & $\mathrm{NOL} \dagger$ & $\mathrm{NOL}^{*}$ \\
\hline 213 & WHI & WIK & $\mathrm{Y}$ & $15(15)$ & $?^{* \star *}$ & NEL (4) & $\mathrm{NEL}^{*}$ & $\mathrm{NEL}^{*}$ & $\mathrm{NEL}^{*}$ & NEL* \\
\hline
\end{tabular}

Each row represents one offspring in the study. Offspring are listed in alphabetical order by concensus father, then by mother. Concensus father is the male assigned as father considering information from all methods.

$\ddagger$ CERVUS analysis including all sampled males (adults, subadults) that were in the population at the time of conception. In no case did CERVUS assign an extragroup male as the father; in all cases where we assigned paternity to genotyped males, the CERVUS run that included all males in the population yielded the same result as other runs and as our exclusion analysis.

*95\% confidence by CERVUS.

$\dagger 80 \%$ confidence by CERVUS.

$\S$ Subadult at time of conception (see text).

**Present in group but not genotyped. All other males in population excluded at multiple loci.

††Mismatch between mother and offspring despite genotyping from multiple samples. No paternity assigned.

ttPaternity was not assigned because problems were encountered with genotyping PES (see text).

$\S \S T$ o be conservative, no paternity was assigned because neither male could be excluded.

${ }_{* * *}$ To be conservative, paternity was not assigned because the most likely father was excluded at four loci. 